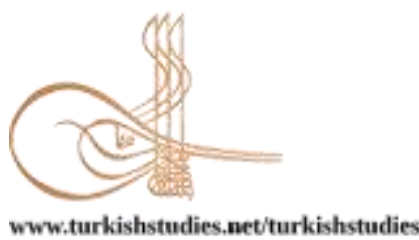

Turkish Studies

\title{
Vatan Arketipi Bağlamında Âşııların (Mecnûn, Ferhâd, Cemşîd) Vatan-ı Aslî ve Vatan-ı Seferîleri
}

\author{
Principal Motherlands and Expeditionary Motherlands of Lovers (Mecnûn, Ferhâd, Cemşîd) in the \\ Context of the Motherland Archetype
}

\author{
Hacer Sağlam*
}

\begin{abstract}
According to philosophers and Sufis, there is an absolute equivalent to every element, which exists in the physical world, in the metaphysical world. Plato refers to this with the concept of "idea", Jung with the concept of "archetype" and Ibnu'l-Arabî with the concept of "the ayân-1 sabite". The aforementioned concepts, although not completely identical with each other, show similarity in regard to attracting attention to noumenon properties of the phenomena. Considering the structure of creatures arising from the initial image, it is concluded that the term "motherland" also originates from an absolute essence. Motherland today signifies a social-political meaning and this meaning is solely the result of an earthly perception. Considering from a religious and sufistic perspective; motherland points out the place also where the spirit belongs to. Thus, motherland appears in two forms including spirit and body. The motherland essentially adopted by spirit and body is principal motherland, while the spaces outside the principal motherland are expeditionary motherland. Characters in love in the divan literature draw attention with their placelessness and instability. Of these characters the primary one is Mecnûn, who is the king of lovers. As a person choosing an isolated lifestyle, Mecnûn has no space and thus no motherland. Instead of a specific space, he adopts spaces like mountains, deserts, caves and the lover's neighborhood as principal motherlands. The lover is on an expeditionary motherland outside these motherlands and always seeks to return to the principal motherland. It is seen in the mathnawis that Farhad who is in love with Sirin and Cemsid who is in love with Hursid, adopt the same spaces as their motherland under the influence of Mecnûn. In this paper the principal motherlands and expeditionary motherlands adopted by the lovers of the divan poetry, will be examined in terms of their earthly and spiritual characters and their meanings in the mathnawis, from the perspective of Mecnûn and Farhad and Cemsid who adopt the same spaces as motherland with Mecnûn.
\end{abstract}

Structured Abstract: The term "motherland" came into prominence with Namik Kemâl in the Turkish literature and this novelty brought along the necessity of examining the perception and nature of "motherland" in the divan literature retrospectively. In the studies it has been concluded that the concept of motherland is used and comprehended in completely different meanings in the divan literature from the Tanzimat (Reform) poetry.

In the divan literature, motherland is far from an earthly perception of space. In an era dominated by a transcendental thought and lifestyle, the view to the concept of motherland would necessarily course in line

\footnotetext{
*Arș. Gör. Dr., Kafkas Üniversitesi, Fen-Edebiyat Fakültesi, Türk Dili ve Edebiyatı Bölümü. Res. Asst, Dr., Kafkas University, Faculty of Science and Literature, Department of Turkish Language and Literature. ORCID 0000-0002-9606-6367.

ediybe@gmail.com

Cite as/ Atıf: Sağlam, H. (2021). Vatan arketipi bağlamında âş1kların (Mecnûn, Ferhâd, Cemşîd) vatan-1 aslî ve vatan1 seferîleri. Turkish Studies, 16(1), 313-355. https://dx.doi.org/10.7827/TurkishStudies.47771

Received/Geliş: 20 November/Kasım 2020

Accepted/Kabul: 20 Şubat/February 2021

Checked by plagiarism software

Published/Yayın: 25 Şubat/February 2021

CC BY-NC 4.0
} 
with this perception. In the divan literature, motherland refers to the place a person is born into and belongs to, independently from the social-political meaning, in a narrow sense; whereas in a transcendental sense it contains much deeper meanings. For a person comprehending that the world is mortal and the afterlife is immortal, motherland is fed from an extraterrestrial space perception. The first of these is the bezm-i elest (assembly of spirits). The bezm-i elest is the principal motherland where the spirits get a body before coming to the world. The motherland where a true believer always seeks to return to is the bezm-i elest. Heaven where the spirit will meet God is the second principal motherland. Heaven is another principal motherland giving the chance of returning to the eternity after the earthly motherland. For the true believer longing for these two motherlands, the world is nothing but an expeditionary motherland.

Thus, motherland appears in two ways as principal and expeditionary. The motherlands expressing the place where one belongs to are principal; while the motherlands that are considered temporal are expeditionary.

The fact that motherland has principal and expeditionary types, notifies the "absolute existence" of the concept of motherland. Fictional existence arising from the space reveals the cooccurrence of existence with space and time built on space. Domination of time is undoubtedly possible only through the existence of space. Existence of space has a fictitiously extraterrestrial existence and nature. Depending on space, motherland also originates from an extraterrestrial essence.

Within the frame of the understanding that every element in the world originates from an initial image, motherland appears as an "idea" and "archetype". As concepts chosen by Plato and Jung, idea and archetype do not refer to the same meaning. However, they might be accepted to be equivalent because they both attract attention to noumenon properties of the phenomena. Ibnu'l-Arabî refers to the same nature with the concept of "ayân-1 sabite". The constant essences indicated by Ibnu'l-Arabî as "ayân-1 sabite", constitute the essence of ideas and archetypes. Idea, archetype, and ayân-1 sabite will eventually separate and unite at certain points. Actually, they cover a common meaning in regard to referring to the extraterrestrial constant nature of existence elements in the world.

According to Ibnu'l-Arabî there are many motherlands and there are six motherlands where humans live. They are bezm-i elest (the assembly of spirits), dünya (world), berzah (intermediate realm), haşr (gathering), cennet-cehennem (heaven-hell) and Sand Hill (Kum Tepesi/el-Kesib). The bezm-i elest forms the first motherland, and the dünya (world) forms the second one. The motherland after death is the berzah (intermediate realm) and the motherland where spirits will gather on the doomsday is the haşr (gathering). The motherlands assigned according to the person's labor are heaven and hell. The final motherland is the Sand Hill (el-Kesib) where God will be met. El-Kesib is outside the Firdevs heaven $\left(6^{\text {th }}\right.$ garden in heaven) and it is the motherland where people will be present according to their deed level.

Of these motherlands mentioned by Ibnu'l-Arabî; the dünya (world), berzah (intermediate realm), and haşr (gathering) constitute the expeditionary motherlands. Posing a spatial obstacle to the spirit's eternal peace and happiness; expeditionary motherlands do not give pleasure to true believers. True believers will feel eternal happiness that they desire so much only in the principal motherland.

In the divan poetry, the lover refers to the transcendental existence and the existence elements related to him are also idealized, which has affected the view of the concept of motherland as well. As motherlands in the divan are spaces to reach the transcendental existence for poets, they only consist of the bezm-i elest and heaven in particular. The sense, mentioning that the spirit sees the place it belongs to as motherland, originates from its archetypal nature mentioned earlier. This nature also causes lovers to see the lover's neighborhood as the principal motherland. The metaphoric lover is a copy and reflection of specific qualities of the divine lover, which makes the lover's neighborhood also a copy and reflection of the motherland where the divine lover is reached. Thus, besides the bezm-i elest and heaven; the metaphoric lover's neighborhood comprises one of the principal motherlands of the lover, just like the Kaaba.

The existence of principal motherlands necessitates mentioning the existence of expeditionary motherlands as well. In the mathnawi, lovers abandon their family home once they fall in love. Although this initially proves the lover's placelessness / statelessness / instability, the fictional existence of the motherland brings along the necessity for the lover to adopt new spaces for motherland in his transformation process. The leading lover of the divan poetry; Mecnûn as a lover who experienced this transformation preeminently, 
accepted the mountains, deserts, caves, and the lover's neighborhood as his principal motherlands after abandoning his family home.

Mecnûn's impact on mathnawis was seen in the same way for the characters of Farhad and Cemsid, who are the other lovers. In the transformation process from metaphoric love to divine love, Farhad and Cemsid also accepted the mountains, deserts and the lover's neighborhood as their principal motherlands, just like Mecnûn. New motherlands and the nature of these motherlands might be perceived as spatial support elements of the transformation process for lovers.

In this article, the habitation of the characters of Farhad and Cemsid will be examined in respect of their principal and expeditionary types and their earthly and spiritual natures on the basis of Mecnûn.

Keywords: Divan literature, motherland, Mecnûn, Farhad, Cemsid.

Öz: Düşünürler ve mutasavvıflara göre, fizikî âlemde var olan her unsurun, metafizik âlemde mutlak bir karşılığ1 vardır. Platon, bunu “idea”, Jung “arketip”, İbnü'l-Arabî ise, "ayân-1 sabite” kavramları ile karşılar. Birbiri ile tamamen aynı olmamakla birlikte, söz konusu kavramlar, fenomenlerin numen özlerine dikkat çekmesi bakımından benzerlik arz eder. Varlıkların, ilk imgeden kaynaklanan yapıları dikkate alındığında, "vatan" tabirinin de mutlak bir özden kaynaklandığı sonucuna ulaşılır. Vatan, günümüzde siyasî-sosyal bir manâyı ifade etmekle birlikte, bu anlam, yalnızca dünyevî bir algının sonucudur. Dinî ve tasavvufî perspektiften bakıldığında, vatan, ruhun ait olduğu yere de işaret eder. Böylece vatan, ruh ve bedene ait olmak üzere iki şekilde ortaya çıkar. Ruhun ve bedenin aslî olarak benimsediği vatan, vatan-1 aslî; vatan-1 aslî dışındaki mekânlar ise vatan-1 seferîdir. Divan edebiyatının âşık kahramanları mekânsızlığı ve karârsızlığı ile dikkat çeker. Bunların başında âşıkların şâhı Mecnûn gelir. Tecrid hayatını seçmiş bir âşık olarak Mecnûn'un bir mekânı ve dolayısıyla vatanı yoktur. Belli bir mekân yerine, dă̆, çöl, măgara, sevgilinin kûyu gibi mekânları, vatan-1 aslîler olarak benimser. Âşık, bu vatanlar dışında vatan-1 seferîde olup, daima aslî vatana dönme seyri izler. Mecnûn'un etkisi ile Şîrîn'e âşık olan Ferhâd ve Hurşîd'e âşık olan Cemşîd'in de mesnevîlerde aynı mekânları vatan edindiği görülür. Bu makalede, Mecnûn ve Mecnûn ile aynı mekânları vatan edinen Ferhâd ve Cemşîd çerçevesinde, Divan şiiri âşıklarının benimsediği vatan-1 aslî ve vatan-1 seferîler, dünyevî ve manevî mahiyetleri ve mesnevîler içerisindeki anlamları bakımından ele alınacaktır.

Anahtar Kelimeler: Divan edebiyatı, vatan, Mecnûn, Ferhâd, Cemşîd.

\section{Giriş}

Türk edebiyatında Namık Kemâl ile ön plana çıkmaya başlamış olan "vatan" kavramı, zaman zaman divan edebiyatı araştırmalarının da konusunu oluşturmuştur. Vatan bir tem olarak divan şiirinde, Tanzimat şiirindeki gibi yer almamakla birlikte, dönemin zihniyeti çerçevesinde birtakım manâ ve mahiyetleri taşımaktaydı. Divan şiiri şairleri için vatan, siyasî-sosyal boyuttan bağımsız olarak genellikle kişinin dünyaya gelip yaşadığı yeri ifade etmekteyken esasında vatana bakış, ait olunan yer manası bakımından manevî bir mahiyeti göstermektedir.

Vatan, genel olarak ait olunan yeri içermekle birlikte, aslî ve seferî vatan çeşitleri, benimsenmeyen mekânların da vatan çerçevesinde bulunduğunu ifade etmektedir. Vatanın aslî ve seferî daireden bağımsız olamaması, onun değişmez bir öze sahip olduğunun birincil göstergesi ise, dönem-zihniyet ve kişiye göre değişen mahiyetine rağmen varlığını koruması da bir diğer göstergesidir. Vatan algısının dünya üstü bir öze sahip olması, bu bakımdan, onun imgesel varlığına işaret etmektedir.

Vatan, imgesel mahiyeti nedeniyle dönem, zihniyet ve şahsî algının etkisi doğrultusunda şekillenebilmektedir. İbnü'l-Arabî’nin sudûr nazariyesi açısından bakıldığında, vatan, ayân-1 sabitelerin bir yansımasıdır. Vatanın, mutlak mevcûdiyete işaret eden imgesel varlığı, mekânsızlığı / vatansızlığı / karârsızlığı ile bilinen divan edebiyatındaki âşık tipinin de vatandan bağımsız olmasının imkânsızlığına işaret etmektedir. Bu nedenle "lâ-mekân" olan âşığın, kendi seçtiği mekânlar da olsa bir idea ve arketip olan vatandan kopamadığı görülmektedir. 


\section{1. İdea, Arketip, Ayân-ı Sâbite}

İlk olarak Platon'un tikel varlıkların tümel hakikate dayanan özü fark etmesi ile ortaya çıkan "idea" kavramı, duyuların ötesinde, akılla kavranabilen birliğin varlığını ifade eder. Değişen ve sûretlerden ibaret olan bu duyular (oluş) âleminin ötesinde, akılla kavranan, sabit, tümel bir asıl / öz varlık dünyası vardır. Platon'a göre idealar, duyular dünyasında görülen her şeyin ilk örnekleri (arketip) veya önceden var olan örnekleridir (prototip) (Ülken, 2008: 84).

Jung'un birer form ve içeriklerden oluşup Platon'un idea kavramıla özdeş olduğunu belirttiği arketip, tıpkı idea gibi, varlıkların dış dünyadaki görünümlerinin kendisinden kaynaklandığı "ilk imge" anlamını taşır. ${ }^{1}$ Jung, insan eylemlerinin a priori ${ }^{2}$ bir nitelik taşıdığını, bireysel ve kolektif bilinçdışının ilk insandan itibaren kalıtım yolu ile bireyden bireye aktarıldığını savunur. Jung'a göre, idea veya arketip, işte bu a priori niteliklerdir (Bk.: Jung, 2017: 17-18).

İbnü'l-Arabî'nin Yeni Eflatunculuktan etkilenerek sistematize ettiği öne sürülen tasavvuf nazariyesi, sudûr teorisi esasına dayanır. ${ }^{3}$ İbnü'l-Arabî'nin nazariyesinin temelinde, "varlık olmak bakımından varlık Hak'tır" düşüncesi vardır. Bu düşünceye göre, her varlık, tek bir özün tecellî ve tezahüründen başka bir şey değildir (İbnü'l-Arabî, 2019: 15).

İbnü'l-Arabî'ye göre, Feyz-i Akdes'ten meydana gelen ilk tecellî ile mutlak birlikteki isimler, Allah'ın bilgisinde ayrışarak tek tek isimler veya bu isimlerin sûretleri olan ayân-ı sabite olarak var olur (taayyün) (İbnü'l-Arabî, 2019: 27). Ayân-1 sabiteler, "suver-i ilmiyye" (ilmî sûretler) diye isimlendirilir ve mümkünlerin Allah'ın bilgisindeki hakikatleri anlamına gelir. Allah'ın esmasının birer sûretleri olan ayân-ı sabiteler, varlıkların asıllarını oluşturur ve şehadet âlemindeki varlıkların özüdür. Bu öz, değişmez bir niteliğe sahip olduğu için "sabit aynlar" olarak belirtilir. İbnü'l-Arabî, ayân-1 sabiteleri, "mahiyet, Rabbanî latife, hakikat” kavramları ile de karşılar (İbnü'lArabî, 2019: 253).

Arketip, idea ve ayân-1 sabite kavramları, varlıkların fenomen ${ }^{4}$ ve numen ${ }^{5}$ olmak üzere iki yönlü bir mahiyete sahip olduğu anlamını taşıması bakımından müşterek bir özü karşılar. Bunlardan, arketip (arche-type), "ilk imge" anlamıla Jung'un ifade ettiği şekilde, görünenin ardındaki öz, diğer deyişle simgenin ötesindeki "ilk imge" olmak bakımından idea ile aynı manâyı içerir. Arketip ve idealar, tikel varlıkların hakikatlerini içermek anlamıyla eşdeğer nitelik taşır. Ancak, idea, aynı zamanda "iyi ideası"na bağlı olmakla tümel hakikate dayanan yönü de ifade eder. Bu bakımdan idea, arketip ile eşdeğer olmasına rağmen, "iyi ideası" ayân-1 sabiteye daha yakın bir kavram olma özelliği gösterir. ${ }^{6}$

\footnotetext{
${ }^{1}$ Jung, anne, yaşlı bilge, gibi çeşitli kişisel arketipleri sıralarken bunların esasında zihinde kodlanmış özlerle kayıtlı olduğu düşüncesinden hareket etmiştir. Birtakım kişisel arketipler üzerine kurduğu psikolojik açılımlarında bu kodların kaynağından yola çıkması için, ilk imge alt yapısına ihtiyacı vardır.

2 "Önden, önceden olan" manasındadır. Önsel bilgi, Platon'dan beri felsefede üzerinde durulan bir sorundur. Önsel bilgi, doğuştan, spontan bir şekilde oluşan bilgi olarak tanımlanır. A priori nitelikteki bilgi, dış dünyadan tecrübe yolu ile değil, ak1l yoluyla edinilmiş bilgiyi ifade etmektedir. (Bk.: Akarsu, 2016: 141; Cevizci, 2020: 157).

3 İbnü'l-Arabi'nin sudûr teorisi üzerine kurduğu tasavvuf nazariyatı, kimi araştırmacılara göre, Hint, Ârî ve Yeni Eflatunculuk olmak üzere üç kaynaktan etkilenmiştir. Ancak Afifi, tasavvufun İslam tarihinin bir ürünü olup İslam diş1 görüşlerden etkilenmiş olduğu kanaatindedir. Geniş bilgi için bk.: Ebu'l-Alâ Afîfî, 2018: 54-62. Ayrıca bk.: Nicholson, 2018.

${ }^{4}$ Felsefe alanı terimi olan "fenomen", "görüngü”, (TDK, 2005) manâsındadır. Mahmut Erol Kılıç, fenomen'e "zâhir" manâsını verir. Bk.: Kılıç, 1995: 3.

${ }^{5}$ Felsefe alanı terimi olan "numen", "nesnenin kendisi, görüngü karşıtı”, (TDK, 2005) mnâsındadır. Mahmut Erol Kılıç, numen'e "bâtın" manâsını verir. Bk.: Kılıç, 1995: 3.

${ }^{6}$ İdealar, bütün ideaların kendisinden geldiği iyi ideasına bağlı olması bakımından Mutlak Cemâl'den zuhur eden ayân-1 sabitelerle aynı manayı içeriyor görünmektedir. Nitekim Platon, yaratıcı tanrı Demiourgos'un yanında güneşe benzettiği iyi ideasını biçim veren tanrı gibi düşünmüştür. Platon, 2007: 277-282.
} 
Ayân-1 sabiteler, imgelerin tek bir özden kaynaklandığı düşüncesine bağlı olmaları bakımından Jung'un arketip ve Platon'un idea kavramlarından ayrılır. ${ }^{7}$ Arketipler de kalıtımsal olmaları, varlıkların yeryüzündeki ilk görünüşlerinin genetik aktarımlar vasıtasıyla yaşamasını ifade etmesi bakımından ayân-1 sabitelerden ayrılır. Ancak belli noktalarda farklılaşmakla birlikte, arketip, idea ve ayân-1 sabite, varlıkların numen ve mutlak hakikatlerine işaret etmeleri bakımından eşdeğer kavramlardır, denebilir.

\section{2. "Vatan" ve "Sefer" Arketipleri}

\section{1. "Vatan" Arketipi}

Vatan, "kişinin doğduğu, yerleştiği, barındığı ve yaşadığı yer" mânasına gelir. "El-mevtın" (çoğulu: mevâtın) (Çağrıc1, 1995: 563-564; İbnü’l- Arabî, 2018: 13; Mutçalı 1995: 563-564) da "vatan" ile aynı anlamda kullanılır. Aynı kökten gelen îtân ve tavattun, "bir yeri vatan edinmek" demektir (Çağrıc1, 1995: 563-564; Mutçalı 1995, :992; Ş.Sami, 1987:451-52).

Mekân, oluşun meydana geldiği yer (Kutluer, 2003: 550-552) olarak vatanı kapsamına alır. Bulunulan mekânın vatan olması, köklerin oraya ait olması veya oraya ait hissetmek ile mümkün olabilir. Vatan konusunda eser kaleme alan ilk müelliflerden Câhiz'e göre, vatan sevgisi ve vatan hasreti doğuştan gelen bir duygudur. İnsanların vatanlarında bulunmayı rızıklarından daha fazla önemsemeleri, bu fitrî duygu ile ilgilidir (Çağrıcı, 1995: 563-564).

Esasında vatan sevgisi veya bir mekânı vatan edinme gereksinimi, dünyevî her olgu için olduğu gibi, dünya üstü bir özden kaynaklanmaktadır. Her fenomenin bir numen öze sahip olduğu veya her simgenin bir ilk imgeden kaynaklandığı görüşünden hareketle vatan duygusunun dünya üstü bir hakikate dayandığı çıkarımına varılabilir. Buna alt âlemde var olan her unsurun üst âlemde zorunlu / mutlak bir karşılığı vardır da denebilir. Bu nedenle mekânın yurt edinilmesi ile ortaya çıkan tavattun, âlemin yaratılışı bahsine kadar gider.

İbnü'l-Arabî'ye göre, tecellî ve taayyünle zuhura gelen âlemler, isimlerin ve mertebelerin nikâh-1 manevîsi sonucu oluşmuştur. Nikâh-1 manevînin oluşması, eril ve dişil mertebelerin çocuklarının diğer bir alt mertebeyi meydana getirmesi ile devam eder. Yaratılışta dişil mertebeler, tecellîlerin mekânlarını oluşturur. İlk olarak Uluhiyyet perdesi olan 'Amâ' dan kuşatıcı varlık dairesi olan Arş'ın mukaddes tahtına "Rahman" ismi istivâ etmiştir. Rahman ve kuşattığı isimler, bu üstten, âlemi yönetmektedirler (İbnü’l-Arabî, 2018: 13).

İstivâ, "karar kılmak, oturup yerleşmek, hâkim olmak, tahtta oturmak" manâlarına gelmektedir. Genel görüşe göre, Allah'ın Arş'a istivâsı, Arş'a esması ile kurulması manâsındadır (Yavuz, 2001: 402-404). İbnü'l-Arabî, mukaddes taht olarak tavsif ettiği Arş'ın bir kıralının olması gerektiğini belirtir (İbnü'l- Arabî, 2018: 13). İstivâ, "kurulmak, hâkim olmak" manâsı bakımından elbette "tavattun"dan farklıdır. Tavattun, kişinin mekânı vatan edinmesi, oraya ait olması; aidiyet geliştirmesi demek iken istivâ, mekâna ve söz konusu mekânın kapsadığı tüm mekânlara sahip ve hâkim olunması manasını verir. Allah için tavattun söz konusu edilemeyeceği gibi, insan için de istivâ söz konusu edilemez. Ancak her iki durumda da mekân ile kurulan bir bağlantının mahiyeti görülebilir. Bu itibarla Allah'ın Arş'a istivâsı, insanın bir mekânı vatan edinmesinin hakikati ve mahiyetidir. Bu bakımdan, tavattun, istivânın bir cüz'ü veya sûreti, "ilk imgesi” olarak karşımıza çıkar.

Yaratılış mertebesinde Amâ'dan sonra, Arş'tan önceki ilk varlık, Nûr ism-i şerifinin tecellîsi ile Akl-1 Küll'dür. Akl-1 Küll / Akl-1 Evvel / Kalem-i A'lâ, Nefs-i Küll / Levh-i Mahfuz olan gölgesini, nefsini görmüştür. Akl-1 Küll (eril) ve Nefs-i Küll'ün (dişil) nikâh-1 manevîsinden ise Hebâ meydana gelmiştir. Hebâ, heyûla, modern fizik terminolojisinde, atomdur (Muhammed Hacı Yusuf,

\footnotetext{
${ }^{7}$ Süleyman Uludağ, ideanın, ayân-1 sabiteden farklı olarak tümel hakikate dayanmadığı, idelerin sadece eşyanın genel sûretleri için söz konusu ve müstakil olduğunu, yani Allah'a bağlı olmadığını ifade eder. Bk.: Uludağ, 1991: 198-199.
} 
2019: 39-41). Hebâ, Hakikat-i Muhammediyye'yi ortaya çıkarması bakımından mekân görevini üstlenmiştir (İbn Arabî, 2019: 339).

İbnü'l-Arabî, yaratılış ve zuhura gelişin bundan sonraki bütün mertebelerinde nikâh-1 manevî ve çocuk sembollerini kullanmıştır (Hacı Muhammed Yusuf, 2019: 43). Nikâh-1 manevîdeki Amâ, Nefs-i Küll, Hebâ, Cism-i Küll, Arş, Kürs gibi bazı mertebeler, dişil varlık mertebelerini oluşturmak bakımından mekânların aslıdır. Mekânlar ise, vatanların aslıdır.

Üst âlemde zuhura gelen bu mekân ilk imgesi, insanın edindiği / edineceği vatanların hakikatini oluşturur. Dünyada bir vatan edinme, insanın, dünyaya nüzulünden önce edindiği vatanın bir sûreti, kopyasıdır. Her türlü vatan, bu arketipe işaret etmektedir. Dolayısıyla tavattun, insanın dünyadan önce ve dünyadan sonra edineceği vatanları kapsaması bakımından oldukça geniş bir yelpazede ele alınabilir.

\subsubsection{Vatanların Asılları}

İbnü'l-Arabî, İttihâdü'l-Kevnî adlı eserinde, insan için vatanların sayısız olduğunu, bununla birlikte, bu sayının altıya indirgenebileceğini ifade ederek söz konusu vatanları şöyle sıralar:

\section{Bezm-i Elest}

2. Dünya

3. Berzah

4. Haşr

5. Cennet ve Cehennem

6. Cennetin Dışındaki Kum Tepesi (el-Kesîb) (İbnü'l-Arabî, 2018: 13-14).

Ruhun ilk vatanı, Bezm-i Elest'tir. Bezm-i Elest, ruhun dönmesi gereken ve istese de istemese de türlü seferlerle dönme sürecinde olduğu vatanıdır. Allah, kulunun, onu bu vatanda bulmasını ister (İbnü'l-Arabî, 2018: 15).

Ruh, taayyün mertebelerinden sefer ederek esfel-i safiline ve oradan da nihayet ikinci vatanı olan dünya vatanına ulaşır. İçinde bulunulan bu vatan, Arabî’ye göre, gökler küresinin içbükey yüzeyinden yerkürenin dışbükey yüzeyine kadar uzanır (İbnü'l-Arabî, 2018: 16). Ruh, sûret kazandığı bu ikinci vatanında çeşitli iç vatanlarda bulunur.

Üçüncü vatan olan Berzah, bu dünya ile öteki dünya arasında geçittir. "İki şeyi birbirinden ayıran engel" manasına gelen berzah, bilinen ile bilinmeyeni, var olanla var olmayanı, inkâr edilenle tasdik edileni, ayrıca aklî olanla gayr-1 aklî olanı birbirinden ayırır (İbnü'l-Arabî, 2018: 16).

Haşr vatanı, insanların kıyametten sonra yeryüzünde tekrar bir araya gelecekleri vatandır. İnsanlar, mezarlarından kalkıp doğrulduklarında yeryüzü uzayıp yayılacak, başka bir yeryüzü olacaktır (İbnü'l-Arabî, 2018: 17).

Beşinci vatan, Cennet ve Cehennem vatanıdır. Cennet, yıldızsız kürenin içbükeyliğiyle semavî menziller, gökler küresinin dışbükeyliği arasında yer alır. Cehennem ise, semavî menziller, gökler küresinin içbükeyliğinden yerin merkezine kadar uzanır. Çünkü yedi gök ve unsurlar, kıyametten sonra şekil değiştirip Cehennem şeklini alacaklardır (İbnü'l-Arabî, 2018: 17).

Altıncı vatan, el-Kesîb, Kum Tepesi vatanıdır. Beyaz miskten yapılmış olan Kum Tepesi, Yüce Allah'1 görme anında mahlûkatın bulunduğu yerdir. Burası, Cennet'in dışında olan Adn Cenneti'ndedir. İnsanlar, Allah'1 ancak burada görebileceklerdir (İbnü’l-Arabî, 2018: 17).

Tüm bu vatanlar, vatanların asıllarını oluşturup diğer vatanlar, bu altı vatanın bünyesinde var olmaktadır. Bu vatanlar içinde de aslî ve seferî vatanlar mevcuttur. 


\section{2. "Sefer" Arketipi}

Her tavattun, bir sefer ile gerçekleşir. Sefer"in ilk anlamı "peçeyi kaldırmak, yüzünü açmak", ikinci anlamı ise "ayrılma, yola çıkma; yolculuk, sefer, seyahat"tir (Mutçalı, 1995: 390-392).

İbnü'l-Arabî, Rahman ismi ve diğer esmanın Arş'a istivâsını Rabbanî seferler olarak adlandırır (İbnü'l-Arabî, 2009: 13). Rahman ismi, Amâ' dan ayrılarak sefer etmiş ve Arş'a istivâ etmiştir. Rahman ismi ile birlikte, esmâ'-i ef'âl de Arş'a istivâ etmiş ve bu isimler, âlemin yöneticileri olmuşlardır. ${ }^{8} \mathrm{Bu}$ itibarla vatanlar, seferlerin gerçekleşme mahalli ve nedenidir. Nitekim Arabî, mukaddes taht olan ve Arș diye tabir edilen kuşatıcı varlık dairesi var edildiğinde, bu tahtın bir kralının olması gerekti (İbnü'l-Arabî, 2016: 14), diyerek istivâ ve seferin birbirine bağlı olduğuna dikkat çeker. Böylece, tavattunun istivâdan kaynaklanan bir öze sahip olması gibi, sefer de Rabbanî seferlere kadar uzanır.

Vatan ve seferin üst âlemdeki varlıkları, dünya vatanındaki ilk örneklerini de aramayı gerekli kılar. Ruh, Akl-1 Küll'den ilk seferinden sonra dünyaya gelerek fizikî âleme ilk seferini gerçekleştirmiştir. Dolayısıyla dünya, onun fizikî varlığının ilk vatanıdır. Böylece, bu sefer ve vatan, genel çerçevede, insanın dünya içinde gerçekleştireceği sefer ve edineceği vatanların ilk prototipi olmaktadır. Bu prototip, elbette ilk olarak Âdem'de görülür. Âdem'in cennet vatanından dünya vatanına nüzulü, vatan ve seferin dünyadaki ilk kaynağını oluşturur. Âdem'in ilk vatanı cennet, ikinci vatanı dünyadır. Âdem, bu vatanda ayrıca iç vatan edinmiş ve bu vatanda sefere çıkmıştır. Sefer için çıktığı ilk varlık ise Havva'dır. Havva'nın vatanı ise, Âdem'dir. Havva, Âdem'den sefer etmiş ve tekrar ona dönmüştür. ${ }^{9}$

Böylece, vatan ve sefer, ilahî boyuttaki ilk imgesi dolayısıyla ilk simge olarak Âdem ve Havva'da ortaya çıkmıştır.

\section{Vatan-ı Aslî, Vatan-ı Seferî}

Vatan-ı aslî veya vatan-ı asl, kişinin ruhsal veya maddî varlığının ait olduğu vatanı ifade eder. Sınırları belirlenmiş, maddî ve manevî kültür unsurlarıyla yoğrulmuş mekânlar, milletlerin anavatanlarıdır. Dünya vatanı içinde yurt edinilen, doğulan ve aile köklerinin ait olduğu yer ise, daha dar anlamdaki vatan (iç vatan, memleket) olarak kabul edilir.

Fikıhta vatan-1 asl, kişinin mesken tuttuğu, daimî olarak yaşadığı yeri ifade eder. Hanefi'ye göre, mümin, vatan-1 aslîsinden ayrıldığında vatan-ı sükna ${ }^{10}$ veya vatan-ı ikâmettedir ${ }^{11}$ (Çağrıcı, 1995: 563-564; Dinî Terimler Sözlüğü, 2009: 25, 326). Tasavvufî terminolojide ise vatan-1 aslî, ruhun Rabb'i ile ilk muhatap olduğu Bezm-i Elest'tir. Ruh, Rabb'inden gelmiş olması bakımından ona ait olduğuna göre, bedenden ibaret olmayan insanın aslî vatanı da Rabb'i ile beraber olduğu mahaldir. Bunun dışındaki mahallerde o, vatan-1 aslîye kavuşma özlemindedir.

Kulun, Bezm-i Elest'e dünyadan sonra dönme umudu yoktur. Kul, Bezm-i Elest'teki birlik hâline hak ettiği ölçüde cennette nail olacaktır. Bu nedenle, vatan-1 aslînin diğer bir mahalli cennettir. Cennet, Âdem'in yeryüzüne inmeden evvel, sûret giydirildikten sonraki ilk vatanı, aynı zamanda, müminlerin haşrdan sonraki dördüncü vatanıdır. Cennetin dışındaki el-Kesîb de diğer bir vatan-1 aslî iken cehennem, ehl-i küfrün haşrdan sonraki vatanıdır. Öyleyse İbnü'l-Arabî’nin saydığı altı

\footnotetext{
${ }^{8}$ Er-Rezzâk, El-Muhyi, El-Mümit, gibi. Bk.: İbnü'l-Arabi, 2016: 14.

9 Yeryüzüne indirildikten sonra Âdem ile Havva'nın nereyi vatan edindikleri konusu net değildir. Bazı rivayetlere göre, Âdem Seylan (Serendib) adasına, Havva da Cidde'ye inmiştir. Daha sonra Müzdelife ve Arafat'ta buluşmuşlardır. Bk.: Bolay, 1988: 358-363.

${ }^{10}$ Bir kimsenin on beş günden az kalmaya niyet ettiği yer "vatan-1 süknâ" ve "vatan-1 seferî"dir. Bk.: Atar, 2009: 294-298.

${ }^{11}$ Bir kimsenin en az on beş gün kalmaya niyet ettiği yer "vatan-1 ikamettir". Bk.: Atar, 2009: 294-298.
} 
vatandan, Bezm-i Elest, Cennet-Cehennem ve El-Kesîb, vatan-1 aslîler olarak belirtilebilir. Vatan-1 aslîler arasında kalan diğer vatanlar ise, "vatan-1 seferî"lerdir. ${ }^{12}$

İbnü'l-Arabî'ye göre, ruh, var olduğu andan itibaren sonsuza dek sürekli sefer hâlindedir. Dünya vatanından sonra kul, berzah vatanına geçer. Berzah vatanını da mahşer izler. Mahşerden ehli olunduğu yere göre, cennet veya cehennem vatanlarına intikal eder. Cehennem ehli olmayan kimse, buradan sonra cennet vatanına geçer. Cennet vatanında da cennet ve Allah'ın cemâlinin müşahede edileceği El-Kesîb arasında devamlı sûrette gidip gelir (İbnü'l- Arabî, 2016: 6-7).

Vatanların değişmesi, seferler ile mümkündür. Geçici vatanlar, vatan-1 seferîdir. Dünya, geçişi ve ruhun ait olmadığ seferîdir. Berzah da ruhun ait olmadığ 1 yer ve geçici olduğuna göre, dünya ile haşr arasındaki vatan1 seferîyi ifade eder. Haşr ise, cennet ve cehennem vatanları için birer vatan-1 seferî konumundadır.

Sonuçta, üzerinde bir müddet kalınan mekân, vatan; asıl ait olunan mekân "vatan-1 aslı̂”; misafir olunan vatan ise "vatan-1 seferî"dir. Vatan-1 seferîde bulunan kimse, misafirdir. Bulunduğu mekân, onun geçici vatanıdır. Ruh, aslî vatanına erişmediği sürece, bu sefer üzeredir. Bu nedenle kararsiz ve huzursuzdur.

\section{Divan Şiirinde "Vatan" ve "Vatan-ı Aslî"}

Modern anlamda, Fransa'da ortaya çıkmış olan "vatan" tabiri, sınırları belli, ulus-devlet anlayışı üzerine kuruludur. Bu anlayışa göre "vatan" fikri, devletin doğal bir kurum olup öbür dünya ile ilgisinin olmadığı görüşü ile temellenir (Gökberk, 2018: 15). Anadolu'nun vatan olarak benimsenmesi, bu anlayış çerçevesinde meydana gelmiştir (Lewis, 2018: 485).

"Vatan" tabiri, Modern Türkiye tarihinde dalgalı bir seyir izlemiştir. Cevdet Paşa'ya göre, on dokuzuncu yüzyılın ortalarında bir Türk askerinin gözünde köy meydanından başka bir şey değilken on dokuzuncu yüzyılın sonuna doğru, Namık Kemâl'e göre, bütün Osmanlı İmparatorluğu'nu ve belki de özellikle kutsal toprakları ifade etmekteydi. Ziya Gökalp için ise, vatan ne Türkiye ne de Türkistan'dı; engin Turan diyarıydı. Yirminci yüzyıla gelindiğinde, Sadrazam Mehmed Said Halim Paşa, "bir Müslümanın vatanının şeriatın hüküm sürdüğü yer olduğu” fikrinde hâlâ 1srarcıydı (Lewis, 2018: 485).

Vatan temi, XIX. yüzyılda, Tanzimat'ın önde gelen şairi Namık Kemâl ile edebiyatımızda geniş yer tutmaya başlar. Namık Kemâl'de vatan sevgisi ve vatan edebiyatı tam bir feveran halindedir. Çağdaş Fransız ve Alman vatan edebiyatının tesiri ile Namık Kemâl, vatanı bir anne ve sevgili olarak tasavvur eder (Banarl1, 1972: 57-61).

Osmanlılar, bugünkü manâdaki "vatan" kelimesinden ziyade, "mülk", "memâlik" ve "memleket" kelimelerini kullanmışlardır. Osmanlı için bütün topraklar "mülk" olup "mülk" de vatan ile aynı anlamdadır. Sürekli genişleyen topraklara sahip ve bir fütûhât devleti olan Osmanlı Devleti için, ülkenin her tarafı korunması gereken Mukaddes Vatan'dır (Sütçü, 2004: 55). "Tavattun" kelimesinden Türkçeleşmiş olan "vatan tutmak", "vatan edinmek" tabirleri, Müslüman Türk ordularının bir gazâ ruhu ile mücehhez olarak Anadolu ve Balkanlar coğrafyasını fethe başladıkları zamanlarda doğmuştur. Vatan kelimesi, bu manasıyla XIV-XVI. yüzyıllar Türk edebiyatında kullanılmıştır. Örnek olarak; XIV. yüzyıl şairi Ahmedî’nin bir gazelindeki;

Kaddün hayâli dutdu gözümde vatan beli

Her kande serv olsa yeri cûybâr olur

\footnotetext{
${ }^{12}$ Aslında bezm-i elestten başka bir vatan-1 asliden söz etmemek gerekir. Çünkü insan, İbnü'l-Arabi’ye göre, cennette dahi sefer hâlindedir. Ancak, burada divan şiir geleneğinde şairlerin vatan-1 aslî olarak belirttikleri vatanların dikkate alınması bakımından bezm-i elest, cennet, el-kesîb vatan-1 aslî olarak kabul edilmiştir.
} 
beytinde, sevgilinin hayalinin âşığın gözünde vatan tutmasından bahsedilir (Banarlı, 1972: 56).

Divan edebiyatının hüküm sürdüğ̈ süreçte şairler için vatan, geniş anlamda bir mekân anlamını karşılamaktan uzaktı. Osmanlı'da, din temelli zihniyet yapısı, mekân unsurunu tamamlayan vatanı, daha çok dinî çerçevede algılamıştır. Vatan algısının dinî ve tasavvufî temelli olduğu süreçte, vatan, bedenin değil, ruhun mekân tuttuğu yeri ifade etmektedir. Bezm-i Elest, bu bakımdan şairler için vatan-1 aslîdir:

Hırka-1 kâlibi çâk eyleyüp asl-1 vatana

Anda der-hâl sefer-i bî-ser ü pâ oldı dirîğ (Hakîkî) (Sarı, 2016: 217).

Divan şiirinde vatan, "Hubbü'l-vatan mine'l-iman" (vatan sevgisi imandandır) sözüyle vatana duyulan sevgi sebebiyle de anılır:

Bu gurbethânede halk eylemiş bir gûne ülfet kim

Hezârânında bir dil-beste-i hubbü'l-vatan yokdur (Nâbî) (Sarı, 2016: 213)

Vatan-1 aslî, bezm-i elestten sonra, ruhun felaha ereceği cennet ile özdeşleştirilir. Şairler için vatan, Hakk'a vuslatın gerçekleşeceği cennettir:

Felekde âdeme hergiz vatandan özge yer olmaz

Behiştî bâg-1 cennetden 'alâmetdür bana Vize (Behiştî) (Sarı, 2016: 218)

Vatan temi, Divan edebiyatında siyasî boyuttan bağımsız olarak çeşitli anlamlarda kullanılır. Nâbî’nin aşağıdaki beytinde vatan, “doğulan yer” manâsındadır:

Vatana varsam iktidârım yok

Bunda dursam medâr-1 kârım yok (Nâbî) (Sarı, 2016: 233)

Vatan, Cem Sultan için, ayrı düşülen memlekete bir hasret nedeni iken ${ }^{13}$ ekseri şairler için mahal, yer, kûy, şehir gibi kelimelerle birlikte, sevgilinin semtini ifade eder (Sarı, 2016: 231).

Can dimağına erüp bûy-1 vatan

Dil diler kim görüne rûy-1 vatan (Cem Sultan) (Sarı, 2016: 212)

Tahkiyevi eserlerin, aynı zamanda reel hayatın da temel unsurları olan kişi, olay, zaman, mekân'ın "mekân" unsurunu ifade eden vatan, varlığın ait olduğu yer olmaksızın varlık göstermesinin imkânsızlığına işaret eder. ${ }^{14} \mathrm{Bu}$, kimi zaman siyasî bir nitelik kazanıp aslî unsurun bir sûreti olurken kimi zaman sevgilinin mahalline işaret eden soyut bir mahiyete bürünür. Esas huzursuzluk ise, "ruh"un aslî vatanından uzakta oluşundan kaynaklanmaktadır. Vatan-1 aslî olan bezm-i elest ve cennetten uzak olan ruh, fizikî dünyada yaşadığı yerden uzakta iken bu huzursuzluğu "hatırlar", yakında iken de zahir olmak isteyen bu huzursuzluğa soyut nedenler bulur. Sevgilinin mahallini vatan olarak kabul etmek bunlardan biridir. ${ }^{15}$ Aşk, kalbi vatan tuttuğunda, âşık da maşuğun mahallini vatan tutmak ister. Divan şiirinde en sık görülen vatan-1 aslî bu nedenle, maşuğun mahallidir:

\footnotetext{
${ }^{13}$ Nihad Sami Banarlı, Cem Sultan'daki vatan sevgisi ile Namık Kemal'in, Tevfik Fikreti'in, Süleyman Nazif ve Yahya Kemal'in şiirlerindeki vatan sevgisinin aynı olduğunu ifade eder. Bk.: Banarlı, 1972: 57.

${ }^{14}$ Dişil formlar olan mekânlar, sahip olunan değil, ait olunan yerlerdir. Bir yerli olmak, bu nedenle o yere sahip olmak değil, ait olmaktır.

15 İnsan, tevhid üzere daimi bir seferdedir. Sevgili ile bir olmak zahiri bir tevhiddir. İlahi aşk ile buluşmamış kalp, elbette tevhidi dünyevi sevgilide, vatanını da onun mahallinde arayacaktır.
} 
Dü cihân terkin urup kılduk kapun cândan vatan

Sürünürüz sâyeveş yanunca ey serv-i çemen (Rahîmî) (Sarı, 2016: 231)

Gül-‘izârum yiri çün bülbülün olur gülzâr

Lâ-cerem bana mahall olsa mahallün vatanum (Edirneli Nazmî) (Sarı, 2016: 231)

Divan şiirinde, gurbet kelimesi vatanla beraber zikredilir. Vatan, insanın doğduğu yer olunca gurbet diyarı da onun mukabili olarak kullanılır (Levend, 1984: 604):

Ey sâkinân-1 bezm-i vatan yâdidin gehî

Gurbet esîri derd ü belâ mübtelâların (Nevres-i Kadîm) (Levend, 1984: 604).

Şairin vatanı dışındaki yer ile birlikte, sevgilinin kûyu dışındaki yerler de gurbetten sayılır. Sevgilinin kûyunun vatan olduğu yerde, oradan uzakta olmak gurbet, uzak olan âşık ise garibdir:

Cüdâ-yı yâra vatanda dinür garîb-i diyâr

Bizüm de meskenümüz kûy-1 yâr olur mı 'aceb (Muhammed Pertev) (Sarı, 2016: 229)

'Aceb var mı garîb olmış benim gibi vatanda

Kat'î suçlu gözi yaşlu hakîr meczûb cihanda (Kuddusî) (Sarı, 2016: 229)

\section{Mesnevîlerde Âşı̆̆ın Vatansızlığı / Mekânsızlığı / Karârsızlığı}

Divan şiirinin ideal âşık tipi Mecnûn'dur. Leylâ vü Mecnûn mesnevîlerinde görülen Mecnûn'un aşk tecrübesindeki hâlleri, Ferhâd u Şî̂în, Hüsrev ü Şîrîn ve Cemşî̀ ü Hurşîd mesnevîlerine de sirayet etmiştir. Bunlardan biri, mekânsızlığıdır. Divan şiirinde âşık mekânsızdır. Bu durum, şairlerce daha çok "bî-karâr", "lâ-mekân" sıfatları ile tarif edilir. Divanelik hâli, âşığın belli bir mekânda karâr tutmasına mâni olur. Özellikle ev gibi sosyal ve medenî hayatın unsurları, âşığın bulunmaktan rahatsız olduğu mekânlardır. Bu nedenle, âşık, sürekli olarak insanlardan kaçtığı gibi, onların karâr kıldığı mekânlardan da kaçar. Âșı̆̆ın sosyal mekânlardan kaçması, "lâ-mekân" olarak anılmasına neden olur. Ulaşmak isteyenler onu aramak zorundadırlar; çünkü âşık, medenî değil, yabanîdir. Sosyal değil, asosyaldir. Vatan sahibi veya mekân-dâr değil; karârsız, lâ-mekândır. Bu yüzden onun ne zaman, nerede olduğu belli değildir. Günlerce süren aramalar sonucu ya bir dağda ya bir mağarada ya da bir çölde, kendisine perişan bir vaziyette rastlanılır.

Leylâ vü Mecnûn mesnevîlerinden diğer mesnevîlere intikal ettiği görülen "karârsızlık", Mecnûn'un devamlı sûrette aranması ile karşımıza çıkar. Oğluna ulaşmak isteyen babası, arkadaşına ulaşmak isteyen Zeyd, Leylâ' dan haber getiren pîr, kabilesi ve diğerleri, günlerce Mecnûn'u aramak zorunda kalırlar. Arayıp bulduklarında ise, iç açıcı bir manzara ile karşılaşmazlar. Örnek olarak; babası, Mecnûn'u divane hâlde ve vahşiler ile bulur:

\section{Nizâmî:}

$51)^{16}$

Etrafını yine birkaç vahşi hayvan sarmış / Mecnûn'u da bir hazine gibi koruyorlarmış (3148-

Şâhidî:

Ciger kûşem diyü gitdi şitâban / İñledü yile keşt itdi beyâban

\footnotetext{
${ }^{16}$ Nizami'den yapılan alıntılar için A.Naci Tokmak’a ait çalışmadan faydalanılmıştır. Bk.: Tokmak, 2013.
} 
Pezer çün gördi bu hâletde anı / Gözünden sıza geldi bagrı kanı (1296-1300) ${ }^{17}$

\title{
Hamdullah Hamdî:
}

Şeb-i gamdan solup taze nihâli / Harâb olmış harâbâd işre hâli $\cdots$

Hemâh kara saçı kalmış libâsı / Anun dahi perişan her pelâsı (472-75) ${ }^{18}$

\author{
Ahmed-i Rudvan: \\ Çün işitdi atası bu kelâmı / Anı bulmağa kıldı ihtimâmı \\ Çü geçdi ‘Âmirī ol kûh u deşti / Görür bir kûşede Mecnûn-1 mesti (37a-b) ${ }^{19}$
}

\section{Fuzûlî̀:}

Sahrâlara dutdı seyl tek yüz / Vâdîlere açdı çeşme tek göz $\cdots$

Düşmiş yere hâk-sâr ü gamnâk / Ahvâli harâb ü sînesi çâk (911-915) ${ }^{20}$

\section{Larendeli Hamdî:}

Görür yatmış vücûdı garka-i hâk / Yaşı yir yir yüzüni eylemiş çâk $\ldots$

Gam-1 dil-berden özge mahremi yok / Figân u nâleden yeg hem-demi yok (1411-17)21

\section{Andelîb:}

“... oğlunı kûh be kûh, deşt be deşt ağtarıp yörür irdi. ... Gördi kim bir dağıng karında bir âdem yatıpdir bir teng ü dârıng câyda âdem haźer kılğu dek ammâ Seyyid ben̄̄ 'Âmirī bir ism okıp özge dem salıp ol cây̆ga bardl. Mecnûn mest ü müstağrlk yatur irdi. Seyyid benī Emīr yüzüge yăgşs nažar salıp gördi kim irse bildi ciger pâresi ve nûr-ı çeşmi 'azīz ferzendi dürür”, (s.98). ${ }^{22} 23$

Âşı̆̆ın mekânsızlığı, vatansızlığı ile aynı anlama gelmektedir. Âşık, âkıl insanlar ile kendini aynı vatana ait hissedemez. Onun bu hissiyat1, insanlar tarafindan "lâ-mekân, karârsız, vatansız" olarak anılmasına neden olur. Tavattundan uzak olma, Hüsrev ü Şîîn ve Ferhâd u Şîrîn ${ }^{24}$ mesnevîlerinde, Ferhâd için de geçerlidir. Şîrîn'in aşkından divaneleşen Ferhâd'in yeri yurdu bilinmez. Bu durum, Nizâmî̀'nin Hüsrev ü Şîrîn'inde, Ferhâd'ın ağzından şöyle ifade edilir:

\footnotetext{
${ }^{17}$ Şâhidî’nin mesnevîsinden yapılan alıntılar için bk.: Erbay, 2012.

${ }^{18}$ Hamdullah Hamdî’nin mesnevîsinden yapılan alıntılar için bk.: Güler, 1982.

${ }^{19}$ Ahmed-i Rıdvan'ın mesnevîsinden yapılan alıntılar için bk.: Atatürk Üniversitesi Merkez Kütüphanesi, Seyfettin Özege Bölümü, ASL 414.

${ }^{20}$ Fuzuli'nin mesnevîsinden yapılan alıntılar için bk.: Doğan, 2010.

${ }^{21}$ Larendeli Hamdî’nin mesnevîsinden yapılan alıntılar için bk.: Kütük, 2002.

${ }^{22}$ Andelîb'in eserinden yapılan alıntılar için bk.: Evnak, 1378.

${ }^{23}$ Nevâyî için bk.: Şavk, 2011: 1275-78; Celîlî için bk.: Nas, 2011: 494-507; Celalzade Salih için bk.: Kütük, 1995: 74751; Mektebî için bk.: Levend, 1959: 62; Hâtifî̀ için bk.: Levend, 1959: 79; Halife için bk.: Levend, 1959: 303; Nâkâm için bk.: Piriyev, 2007: s. 24-25.

${ }^{24}$ Söz konusu mesnevîlerin kahramanları üzerine karşılaştırmalı bir inceleme için bk.: Üst, 2014: 47-62.
} 
"Köpeklerin bile dünyada bir yeri vardır, yalnız benim yok! Onlar bile yeryüzünde tutundular da ben tutunamadım! Kaplanların dağlarda, timsahların nehirlerde bir sı̆gınak yerleri vardır. Boynu bükük köşede kalan, yalnız bu zavallıdır!" (Nizâmî, 2012: 244).

Kutb'un Hüsrev ü Şîîn'inde Ferhâd, divane olup yaban ellerini tutar:

Tili sözni ili işni unuttı / Bolup divane tig yabannı tuttı $(2421)^{25}$

\section{Fahrî:}

Aşağu yukaru ararlar-1dı / Ne irerlerdi ne ararlar-1dı (3118)

Eyitdi ger girürsen odağına / Didi kim bırağam baş ayağına $(3157)^{26}$

\section{Ahmed-i Rudvan:}

Cihân u cân içün çekmez melâlet / Gezer 'âlemde rüsvâ vü melâmet (2132) ${ }^{27}$

Mekânı yok cihânda lâ-mekândur / Bu halk içinde bî-nâm u nişândur (2145)

Veli bildür bize ism-i mekânun / Didi ismi olur mı lâ-mekânun (2268)

Azerî İbrahim Çelebi' de Ferhâd, mesken ve diyarını terk eder:

Terk eyledi mesken ü diyârın / Çaldı yire neng ü i’tibârın (794) ${ }^{28}$

Ali Şir Nevâyî̀'nin Ferhâd u Şîrîn'inde de Hüsrev, Ferhâd'a vatanını sorar. Ferhâd, mecnûn birinin vatan kaydından uzak olduğu cevabını verir:

Didi kaydınsin ey mecnûn-1 güm-reh / Didi mecnûn vatandın kayda âgeh (T 153 2029

\section{Ferhâd, aşktan karâr tutamaz ve birden kaybolur:}

\section{Ali Şir Nevâyî:}

Hacâletdin kopup Ferhâd-1 dil-teng / Beliyyet tağı sarı kıldı âheng (TR 81b 12)

\section{Lami'î :}

Bakup gördiler ol can yok arada / Biri biriyle kaldı mâcerâda (3001) $)^{30}$

\footnotetext{
${ }^{25}$ Kutb'un eserinden yapılan alıntılar için bk.: Hacıeminoğlu, 2000. Ayrıca bk. : 2435, 2438, 2470.

${ }^{26}$ Fahrî'nin eserinden yapılan alıntılar için bk.: Gülmez, 2003.

${ }^{27}$ Ahmed-i Rıdvan'ın Hüsrev ü Şîîn mesnevîsinden yapılan alıntılar için bk.: Tavukçu, 2000.

${ }^{28}$ Ayrica bk.: 1088.

${ }^{29}$ Ali Şir Nevâyi'nin Ferhâd u Şîîn mesnevîsinden yapılan alıntılar için bk.: Alpay-Tekin, 2012.

${ }^{30}$ Lami' ̂̀'nin Ferhâd u Şîîn mesnevîsinden yapılan alıntılar için bk.: Esir, 2017.
} 


\section{Ferhâd, ancak aranmakla bulunabilir:}

\section{Ali Şir Nevâŷ̂:}

İki üç hûşmend-i nükte-perdâz / Yiberdi kim k1lıp heryan tek u tâz

Tapıp Ferhâd-1 zâr-1 bî-nevânı / Kitürgeyler bu meclis içre anı (T 12728-29)

\section{Ahmed-i Rudvan:}

Ol âdemler ki göndermiş idi Şâh / Birisinün gözi tuş oldı nâ-gâh

Görür bir merdüm-i matbû' u mevzun / Gezer bir yazıda tenhâ çü Mecnûn (2176-77)

Sâlim'in Hüsrev ü Şîrîn'inde Ferhâd aranıp bulunur:

Sahrâları eyledi tek ü pû / Hurşîd gibi arardı her sû $\cdots$

Nâ-gâh göründü cüst ü çâlâk / Bir kuşede bir civân-1 gamnâk (2865-69) ${ }^{31}$

\section{Azerî İbrahim Çelebi:}

Fi'l-hâl hadem haşem müretteb / Ferhâd'1 arayu gitdiler heb

Her birisi tutdı bir diyârı / Bir güne mekân u reh-güzârı (841-44)

Lâmi'’̂' de Şîrîn'in emriyle Ferhâd aranıp bulunur:

Buyurdı bir niçe peyk-i sabâ-hîz / Uçup her bir yana yol kesdiler tîz $\cdots$

Arayup bulduk o üstâd-1 cânı / Neriman-heybet ü sâm-1 zamânı (3011-14)

Şâhî' nin Ferhâd-nâme'sinde Şâbûr, Şîrîn'in mektubunu Ferhâd'a ulaştırmak için onu dă ve çöllerde arar:

Kal'adan kendüyi idüp per-tâb / Kıldı Ferhâd'ı cüst ü cûya şitâb

Eyleyüp kûhu deşte cümle güzâr / İtdi Ferhâd-1 zârı istifsâr (3748-49)

Nâkâm:

Gehî giryân gehî nalân ü nâlân / Gezerdi sû-be-sû hayrân ü hayrân (330)33

\footnotetext{
${ }^{31}$ Sâlim'in Hüsrev ü Şîrîn mesnevîsinden yapılan alıntılar için bk.: Ayan, 2019.

${ }^{32}$ Azeri İbrahim Çelebi'nin Hüsrev ü Şîrîn adlı mesnevîsinden yapılan alıntılar için bk.: Karakoyun, 2019.

${ }^{33}$ Nâkâm'ın Ferhâd ü Şîrîn mesnevîsinden yapılan alıntılar için bk.: Alper, 2018.
} 
Nâkâm'ın Ferhâd ü Şîrîn'inde Hüsrev'in emri ile mekânı olmayan Ferhâd, aradıktan sonra tesadüfen bulur:

Ne bulmışdı mekânın ne nişânuñ / Kalup hayrân olup nevmidi anuñ

Gezürken nâgehân bir reh-güzerde / Tesâdüf eyledi bir ehl-i derde (386-387)

\section{Hannas Ferhâd'ı arar ve dağda vahşilerle bulur:}

Kılup âmâde bir nâ-merd zâtı / 'Azâzil sūreti Hannâs adı

$\cdots$

Ki mest-i germdür bi-h``iştendür / Be-sân-1 şir-i vahşi kūhkendür

Didi Ferhâd kim yâdıyla yâruñ / Mukimi olmuşam bu kūhsâruñ (724-737)

"Mekânsızlık" durumuna Cemşî́d ü Hurşîd mesnevîlerinde de rastlanır. Cem Sultan'ın Cemşîd ü Hurşîd mesnevîsinde Cemşîd, karar tutmaz haldedir:

Giderdi mihnet ile zâr u şeydâ / Görinmezdi gözine tağ u sahrâ (2817) ${ }^{34}$

Cemşîd, aynı mesnevîde, Mihrâb tarafından bir ay arandıktan sonra dağlarda bulunur:

Bir ay mikdâr Mihrâb aradı anı / Bulamadı şehenşehde nişânı

Bir aydan sonra gördi tağ içinde / Gezer derd ü gam ile dâğ içinde (2961)

Selmân-ı Savecî̀ de, Cemşîd, dağ ve çöllerde aranarak bulunabilir:

Köleler Şahı bulmak için / Dağları ve çölleri aradılar

Bir ay sonra onu bir dağın tepesinde / Yeni doğan ay gibi dertten zayıf ve ince gördüler (636-

$7)^{35}$

Ahmedî' de, Mihrâb, Cemşîd'i iki ay aratıp bulabilir:

Gezüp her yirde ister-idi anı / Arar-1dı anun-çün her mekânı

İki ay isteyü sahrâ-y-1la kûh / Ana irişdiler pür-dûd-endûd (2842-43) $)^{36}$

$\boldsymbol{A} \boldsymbol{b} \boldsymbol{d} \hat{\boldsymbol{\imath}}$ ' de, Cemşîd, mestane halde gezer:

Bu kalbün kalıbın idüp ferâmûş / Gezerdi âlem-i aşk içre medhûş (3256) $)^{37}$

Melik zülf gibi şûrîde-ahvâl / Olup mestânelikle oldı nigû-fâl (3259)

Gulâmân gezdi şehr ü deşt idüp keşt / Bulınamayup arandı ser-te-ser deşt

Geçüp bu hasretile şöyle bir ay / Havâşî vü tavâşî eyler idi vây

\footnotetext{
${ }^{34}$ Cem Sultan'ın Cemşîd ü Hurşî̀d mesnevîsinden yapılan alıntılar için bk.: İnce, 2000.

${ }^{35}$ Selmân-1 Savecî'nin Cemşî̀ ü Hurşîd mesnevîsinden yapılan alıntılar için bk.: Emini, 1996.

${ }^{36}$ Ahmedî’nin Cemşid ü Hurşid mesnevîsinden yapılan alıntılar için bk.: Akalın, 1975.

${ }^{37}$ Abdî’nin Cemşîd ü Hurşîd mesnevîsinden yapılan alıntılar için bk.: Kuloğlu, 1989.
} 
Görildi sonra ol mâh-1 dil-ârâ / Hilâlâsâ idinmiş kûhı me’va (3794-96)

\section{Mihrab, Cemşîd'e vatanını bırakarak gurbeti seçip gittiğini söyler:}

Vatandan gurbet oldı sana muhtâr / Pederle mâder itdün şöyle bî-kâr (3817)

Vatanın arketipsel mahiyeti; âşı̆̆ın, his ve hayâl dünyasında dahi kendini vatandan ayrı düşünememesinde ortaya çıkar. Dünyevî ""memleket", "şehir" gibi mekân adlarının yerini, âşığın belirlediği mihnet, dert, melâmet nevinden hayâl unsurları alır. Ferhâd, vatanının neresi olduğunu soran Hüsrev'e mihnet ve dert şehrinin kendisine mesken olduğunu söyler:

Kim sana vatan ne yirdür üstâd / Cânun ne hevâya oldı mu’tâd $\ldots$

Ferhâd didi ki ey cevân-merd / Mesken bana şehr-i mihnet ü derd (871-73) cevabinı verir:

Celîlî’nin Hüsrev ü Şîrîn'inde, mekânını soran Hüsrev'e Ferhâd, meskeninin melâmet olduğu

Didi ne yirede eylersin ikâmet / Eyitdi meskenüm kûy-1 melâmet (1435) ${ }^{38}$

Kutb'un eserinde ise, Hüsrev'in nereli olduğu sorusuna Ferhâd, "âşıklar şehrinden" olduğu yanıtını verir:

Burun sordı ni yirlig sen tiyü sen / Ayıttı kim âş1klar şehridin men (2520)

Şâhî̉ nin Ferhâd-nâme'sinde Ferhâd, Şîrîn'i gördükten sonra hârâb-âbâd vatan edinir:

Hâne-i mihnete salup bünyâd / Meskenin eyledi harâb-âbâd (1517) ${ }^{39}$

Hüsrev'in vatanını sorması üzerine, tek vatanının mihnetlerin yeri olduğunu söyler:

Kıldı Ferhâd'dan su'âl-i vatan / Didi mihnet-i zemîn tek mihan (3446)

Aynı mesnevîde, Hüsrev, Ferhâd'a karâr ettiği mekânı sorar, Ferhâd, "aşina mülkünün kapısı"nın, makamı olduğunu ifade eder:

Ne yerdür sordı kim dârü'l-karâruñ / Nedür aduñ o yerde kesb [ü] kâruñ

Didi Ferhâd adım bir mübtelâdur / Makâmum dâr-1 mülk-i âşinâdur (429-431)

\footnotetext{
${ }^{38}$ Celîlı̂’nin Hüsrev ü Şîrîn mesnevîsinden yapılan alıntılar için bk.: Nas, 2017.

39 Şâhî'nin Ferhâdnâme'sinden yapılan alıntılar için bk.: Özcan, 2007.
} 


\section{Mecnûn, Ferhâd ve Cemşîd'in Vatan-ı Aslîleri}

İbnü'l-Arabî'ye göre, âlemler, isim ve mertebelerin nikâh-1 manevîsi sonucu meydana gelmişti. Yaratılıştaki dişil mertebeler, tecellîlerin mekânlarını oluşturmaktaydı. Vatanların aslı olan bu üst âlemdeki mekân imgesi, kaçınılmaz sûrette, edinilecek vatanların hakikatini ifade etmektedir.

Toplumsal hayattan soyutlanan âşığın da vatan arketipi gereğince kendine yeni mekânlar bulma ihtiyacı doğar. Tecrid hayatını tercih eden âşık için vatan tutulacak bu mekânlar genel olarak dağ, çöl, mağara ve sevgilinin kûyudur. Nitekim âşık, arandığında bu mekânlarda bulunur.

Divan şiirinde ruhun vatan-1 aslîsi bezm-i elest ve cennet; bedenin vatan-1 aslîsi ise sevgilinin kûyudur. Vuslatın mümkün olmayışı, âşığı, tecrid âlemine sürükler. Âşık, aşkına dağları, çölleri, mağarayı, rakipten firsat buldukça da sevgilinin kûyunu vatan edinir.

Divan şiirinde âşık, sıradan bir âşık olmayıp İdeal Sevgili'ye ulaşma arzusundadır. Bu nedenle, vuslattan ne kadar bahsetse de sevgilinin cevr ü cefâsı onun asıl arzuladığıdır. Âşık için aslolan, âşıklık istidadının ortaya çıkması ve bir seyr-i sülûk tecrübesidir. Cevr ü cefa, bu istidadın açığa çıkmasını ve âşığın aşk mertebelerinde ilerlemesini sağlar. Âşık, bu süreçte, çeşitli mekânlarda çile çıkarır.

Aşkın yuvası, seyr-i sülûktaki uzlet ve çilenin mekânı olarak da düşünülebilir. Nefsin terbiyesi, dar ve eşyadan soyutlanmış, kesretten hâlî olan mekânda gerçekleştirilir. İhlas ve sıdk, ancak halktan kaçınıp onlara olan muhabbeti kalbten söküp atmakla mümkündür (İsmail Ankaravî Dede, www.dosyalar.semazen.net, 2020). Sâlikin, fena bulma seferi, dünyevî bir fena mekânında gerçekleştirilebilir. Âşı ğın, sıradan bir sâlikten farkı, belki sâlikin ulaşma arzusunda olduğu aşka ulaşmış olmasıdır. Sâlik, aşk cevherini tatmak için nefsini tezkiye, kalbini tasfiye eder. Oysa âşık, aşka dûçar olmuş olarak aşkta fenaya geçip maşukta fena sürecine ulaşma yolundadır. Bu nedenle buradaki fark, tam olarak çilenin çıkarıldığı yerden ziyade, vuslata hazırlanmadır. Âşığın yuvasının anlamı, iştiyaktan önce, aşka müştak olmadır. Aşka müştak olma, vecd hâlinin sonuçlarından biridir. Âşık, burada, fenafilmahbub seviyesi olan mecazî vuslata hazırlanır. Aşkın yuvası, onu eğitmek, fena için gerekli olan seviyeye getirmek içindir.

Âşıklar, sevgilide vatan tutamayınca divanelik baş gösterir ve Mecnûn gibi dağları ve çölleri vatan tutarlar. Çeşitli divanlarda şairler, Mecnûn ve Ferhâd'ın dağ ve çölleri vatan tutuşunu sık sık dile getirirler:

İtmişem Mecnûn gibi kûh ile sahrâyı vatan

Tâ giriftâr olmuşam ey gözleri âhû sana (Basirî) (Sarı: 223)

Olalı '1şk ile şî̂în lebinün Ferhâdı

Dil-i dîvâne vatan eyledi taglar etegin (Emrî) (Sarı: 223)

'Işk-1 Leylâ ile Mecnûn eyleyüb terk-i vatan

Mesken itdi kendüsine ulu tağ u çölleri (Kuddusî) (Sarı:227)

\section{1. Âşı̆ı̆ın Vatan-ı Aslîsi Olarak "Dağ"}

René Guénon'un yatay ve dikey boyutların sembolizmine göre, yatay boyutlar pasif ilkeyi (dişilliği), dikey boyutlar aktif ilkeyi (erilliği) temsil etmektedir. İki boyut arasındaki merkez, "erdişil" nokta ve fena noktası, aynı zamanda Âdem-Havva noktasıdır. Burada, eril ve dişil enerjilerden birinin diğerine üstünlüğü söz konusu değildir (Guénon, 2019: 53-55).

Yatay ve dikey boyutların sembolizmi açısından bakıldığında dağ, yatay olan yeryüzünün dikey boyutunu temsil etmektedir. Dağa sığınan kahraman, esasında dişil ve eril boyutları kendinde birleştirmede merkez nokta işlevini görür. Aşk, alma enerjisi (pasif enerji) olarak dişil boyutun bir 
tezahürüdür. Aşk'ın, kalbe kabul edilme ve sığma süreci, bu dişil boyutun son noktasına dek tecrübesini ifade etmektedir. Âşık, pasif enerji boyutunu tecrübe ettikçe dikey boyutta da dönüşümü tecrübe etme sürecine girer. Buna, yatay boyuttaki enerjinin dikey boyutla bütünleştirilmesi de denebilir. Dağ, bu sürecin sembolünü ifade eder.

Tasavvufî̀ literatürde $d a \breve{g}^{40}$, "ricâlü'l-gayb" (gayb erenleri) manâsındaki "evtâd' $1 n^{41}$ temsilidir. Buna göre, Mecnûn'un "dağ" ile dertleşmesi, edebî bir sanat olmanın ötesinde, bu sembolik manâ ile de ilgilidir. Mecnûn'un dağ ile sohbeti, aslında dört kişi olan "evtâd"dan biri ile yapılan sohbetin ifadesidir (Tahral, 1996: 219-220). ${ }^{42}$

Vatan arketipi bakımından, dünya vatanındaki her sûret, üst âlemdeki bir aslı gerektirir. Beşerî sevgili, Allah'ın cemâlinin bir sûreti, sevgilinin mekânı ise, Allah'ın cemâlinin seyredileceği Kum Tepesi'nin bir sûretidir. Kum Tepesi, müminin son vatanıdır. Burası, Adn cennetinde zorlu, güçlü bir yerdir. Öteki cennetlerin dışında bir hisardır (İbn Arabî, 2018c: 17).

Leylâ vü Mecnûn mesnevîlerinde, Necd dağının bulunduğu yerde Leylâ'nın çadırı / evi / sarayı vardır. Mecnûn, Leylâ'nın kûyunu buradan seyretmektedir. Sevgili yücedir, onun mekânı da yeryüzünün en yüce mekânı olmak durumundadır. Âşık, bu zirvede, aşkını da zirve noktasına taşıma seferi verir. Leylâ, cemâlin kemâlinin bir sûreti, meskûn olduğu Necd Dağı da Kum Tepesi'nin bir sûretidir. Kimi mesnevîlerde Leylâ, Necd'de bir saray ve hisar içinde gösterilir. Burası, Mecnûn için ulaşılması zor bir mekândır. Âşık, bu vatana, vatan-1 seferî olan baba ocağından sefer eder (Sağlam, 2020: 251).

Leylâ vü Mecnûn mesnevîlerinin ilk sağlam kaynağı olarak kabul edilen $\boldsymbol{E} \boldsymbol{b} \hat{\boldsymbol{u}} \boldsymbol{B} \boldsymbol{e} \boldsymbol{k} \boldsymbol{r} \boldsymbol{e l}$ Vâlib̂̂̀ nin eserinden itibaren görülen Necd dağında yaşama, diğer mesnevîlerde de aynı şekilde devam etmiştir. Mecnûn, Leylâ'nın kabilesinin meskûn olduğu bu dağın başını kendine mesken edinmiştir. Her nereye giderse gitsin, dönüp dolaştığı yer, yine Necd dağıdır. Bu nedenle, Necd, onun aslî vatanıdır ${ }^{43}$ (Sağlam, 2020: 252):

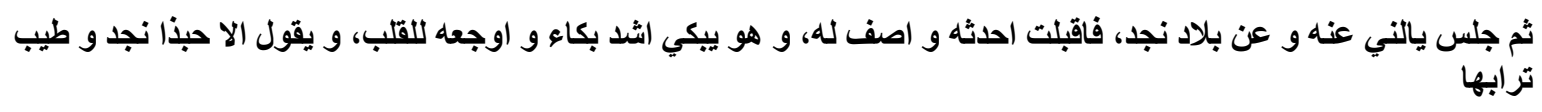

[“Ondan sonra oturdu ve bana onu sordu, Necd ülkelerini sordu, ben de ona anlattım, o da ağlıyor, çok fazla ve kalbi ağrıtan bir şekilde ağlıyor ve diyordu ki: Keşke Necd'de olsaydım, onun toprağını koklasaydım...", Ebû Bekr el-Vâlibî, 1987: 9]. ${ }^{44}$

\section{Nizâmî:}

Oralarda Necid denilen bir dağ varmış / Leylâ kabilesiyle o bölgede yaşarmış

Aşk ateşiyle yanar, dumanı başında tütermiş / Sadece o dağlık yere gelince sakinleşirmiş $(948-50) \cdot{ }^{45}$

\footnotetext{
40 Türklerde dağ bir kült olarak Gök Tanrı ile ilişkilendirilmiş, yeryüzünde Tanrı’ya daha yakın mekânlar olarak kabul edilmiştir. Türkler, dağın bir koruyucu ruhu olduğuna inanarak dağlarda ayin yapıp kurban keserler, dağ iyesinin gücüne inanarak isteklerinin yerine gelmesi için dağlarda dua ederlerdi. (Akt.: Şahbaz, 2018: 2258).

41 "Evtâd", âlemin, dört yönünde görevlendirilmiş dört velidir. Her bir evtâd, bir peygamberin kalbi üzere olup dört büyük meleğin ruhaniyetinden yardım almaktadır. Bk.: Uludağ, 2008: 81-83.

${ }^{42}$ Mecnûn'un sohbeti, Hz. Musa'nın Hak'ın tecellisinin parçaladığı Tûr Dağı'nı hatırlatır. Tûr Dağı'nı tecelliye mazhar oluşu gibi, Hakk'ın seçkin kulları da tecellilerin mazharı olabilirler. Bk.: Eren, 2018: 197-210.

43 İbn Teymiyye'ye göre, "ricâlü'l-gayb” adı verilen gaybın erenleri, mağaralarda ve dağlarda yaşayan, salih kişiler olduklarına inanılan cinlerdir. Bk.: Uludağ, 2008: 81-83.

${ }^{44}$ Ayrıca bk.: Ebu Bekr el-Vâlibî, 1987: 58.

${ }^{45}$ Ayrica bk.: 1005, 2716.
} 


\section{Ahmed-i Rudvan:}

Meger varıdı bir kûh-1 mu'azzam / Ki ismi Necd'idi ğâyetde a'zam $\ldots$

Bu kûh-1 Necd'e ol Mecnûn giderdi / Gözinüñ yaşını ırmağ iderdi (27a) ${ }^{46}$

Celîlî' de, Arkadaşları Mecnûn'u dağı saray gibi kabullenmiş halde bulur:

Kûhsâr ana sarây-1 dil-gîr / Cârûb-1 sarâydur düm-i şîr (1044) ${ }^{47}$

\section{Fuzûlî:}

İhyâ k1luben merâsim-i vecd / Dutdı reh-i gûr-hâne-i Necd (2205-6) ${ }^{48}$

\subsubsection{Dağda Otuz Yıl Geçirme}

Mecnûn, dağda otuz yıl geçirir. Bu süre onun çile sürecidir:

\section{Şâhidî:}

Husûl-1 kâm çün olurdı derhâl / Yüridi nâ-murâd olınca sî sâl (3691) ${ }^{49}$

\section{Larendeli Hamdî:}

Bu resme hâlle Mecnün-1 bî-dil / Geçindi kûh-1 hâmûnda otuz y1l (4401)

\subsubsection{Dağda Kırk Yıl Geçirme} süredir:

Tasavvufta, çilenin süresini ifade eden kırk yıl, Mecnûn'un vatan-1 aslîsinde geçirdiği

\section{Atâyî:}

Bu hâl ile geçer 'ömrüm menim bil / O hâl ilen o dağda geçdi kırh yıl (17a) ${ }^{50}$

Mecnûn gibi, Ferhâd'ın da dağı vatan edindiği, Hüsrev ü Şîrîn mesnevîlerinde görülür. Nizâmî, Kutb, Fahrî, Şeyhî, Ahmed-i Rıdvan, Sâlim, Celîlî tarafından kaleme alınan Hüsrev ü Şîrîn mesnevîlerinde, Ferhâd, Şî̂în'e âşık olmuş ve dağı vatan edinmiştir:

\footnotetext{
${ }^{46}$ Ayrica bk.: 57b, 67b, 91a-91b, 94a.

${ }^{47}$ Ayrica bk.: 495, 955-57, 1808-9.

48 Ayrıca bk.: Dihlevî, 1964: 93, 195; Süheylî için bk.: Abdel-Maksoud, 2004: 112; Camî, 1313: 38; Mektebî için bk.: Levend, 1959: 69; Nevâyî: Şavk, 2011: 858, 2902-19; Behiştî için bk.: Aygün, 1999: 1321-1336; Hamdullah Hamdî için bk.: Güler (1982): 1191-2; Sevdâyî için bk.: Bayak, 2019: 890; Hakiri için: Solak, 2003: 129b/5-6; 157157b/ 11; Lârendeli Hamdî için bk.: Kütük, 2002: 1360-68, 1379, 1398, 1504, 1831-32, 1985, 3815; Celalzade Salih için bk.Kütük, 1995: 891, 901, 957, 1585, 1795-96; Atâyî için: 4b, 10a, 12a, 14b, 41a, 61b; Örfi için bk.: Kütük, 2002: 49, 133, 153-54; Andelîb için bk.: Evnak, 1378: s.36, s.39, 40, 60, 63, 53-54, 78, 124, Nâkâm için bk.: Piriyev, 2007, s.14

${ }^{49}$ Ayrica bk.: 2963, 3213-14, 4311

${ }^{50}$ Atâŷ̂’ye ait beyitler için, Erzurum Atatürk Üniversitesi Merkez Kütüphanesi Seyfettin Özege Bölümü’nde bulunan ASL 644 numaralı yazma eserden faydalanılmıştır.
} 


\section{Nizâmî:}

“Şaşkınlıktan dağ ve sahra yolunu tutmuş, iniltisi dă̆ ve sahraya yayılmıştı." (Nizâmî, 2012: 229).

"Yüreğinde dă̆ kadar gam olduğu halde dăga gitmiş, taş olan bir dağın başında Şîrîn'e olan hasretinden başını taşlara vuruyordu. Nasıl eceli gelen bir sahra ceylanı, yeşilliğine tamahla başına çıkarsa Ferhâd da cünun sahrasından Şîrîn'in visali ümidiyle mezarı olan dağa gitmişti”, (Nizâmî, 2012: 247). edinmiştir:

Ferhâd, Şîrîn'in sûretinin bulunduğu ve köşkünün göründüğü Bî-sütûn dağını vatan

"O nakşın önünde bir müddet zarı zarı ağlar, sonra da uzun zuzun af dilerdi. Oradan tekrar gam yükünü sırtlanarak dağın üstüne çıkar, sevgilisinin köşküne doğru bakar ...”, (Nizâmî, 2012: 239).

Kutb'da, Ferhâd, Bîsütûn dağının tepesinde, bir taş üzerine çöküp ağlar:

Müner ol tağ töpesinge aşukup / Turur yığlayu bir taş üzre çöküp (2585)

Ferhâd, geceleri Bîsütûn'da ağlar, gündüzleri taş keser:

Akıtur közlerindin tün kata yaş / Uzun kün bir zaman tıngmaz keser taş (2652)

\section{Ferhâd, Şîrîn'in dağdaki sûretine bakmaya gider:}

Barıp sûret katınga yıglayu zâr / Tang atgınça yüzin toprakka sürter (2578)

\section{Fahrî:}

Yürürdi dîv gibi âdemden ayru / Düşe dura nite durursa sayru

Gidüpdi tağ u yazıda karârı / Düşüp andan tağa yazıya zârı (3027-28) $)^{51}$

\section{Şeyhî:}

Tolup sevdâ buhârından dimağı / Kodı şehri vü tutdı deşt ü tağı (4380) ${ }^{52}$

Aşağıdaki beyit, Fuzuli ve Ahmed-i Rıdvan'ın eserlerinde de aynı mana ile görülür:

Çü insândan kamu tutmışdı nefret / Ederdi tağda vahşîlerle sohbet $(4395)^{53}$

\section{Ahmed-i Rudvan:}

Arayu gitdiler her bir diyâre / Kimi sahrâlara kim kûh-sâre (2164) $)^{54}$

\footnotetext{
${ }^{51}$ Ayrica bk.: 3078.

52 Şeyhî'nin Hüsrev ü Şîrîn mesnevîsinden yapılan alıntılar için bk.: Timurtaş, 1963.

${ }^{53}$ Çün nefret-i şerr-i nesl-i Âdem / Kıldı ana vahşeti müsellem (Doğan, 2010: 2788) İderdi âdemîlerden çü nefret / Sibâ‘ile kılurdı '1yş u 'işret (Ahmed-i Rıdvan için bk.: Erzurum Atatürk Merkez Kütüphanesinin Seyfi Özege Bölümü'nde bulunan ASL 414, 119a). Diğer beyitler için bk.: 4414, 4645.

${ }^{54}$ Ayrica bk.: 2070, 2075.
} 


\section{Sâlim:}

Mecnûn gibi düşdü deşt ü tağa / ‘Âr eyledi 'aşkdan firâğa (2816)

\section{Azerî İbrahim Çelebi:}

Tağlar yolına revâne oldı / Dîvâne-dil-i zamâne oldı (792) $)^{55}$

\section{Celîlî:}

Çün oldı dâğ-1 '1şkıyla dil-efgâr / Tutar ol lâleveş dâmân-1 kûhsâr (1393)

\section{Ali Şir Nevâyî:}

Tutup ol tağnıng evcide mesken / Bolup hârâ-şikâf u kulle-efgen (TR 78a 31)

Lâmi'î’nin Ferhâd u Şîîn mesnevîsinde Ferhâd, kazdığ dağ̀ vatan edinir:

Salarsa ol hümâ bu yirde sâye / Bana bu tağ ola o çağa pâye

Yüzin çün kıble kûyın Ka’be bildüm / Bu tağ üstinde candan vakfa kıldum (2866-67)

Sehâb-âyîn idüp o kûha 'azmı / Ele aldı yine sengile rezmi (2997)

\section{Şâhî:}

'Azm-i kuhsâr idüp tek u tenhâ / Ağlayup eyler idi vâveylâ

Yaş döküp dem-be-dem idüp zârı / Lâlezâr eyler idi kuhsârı (3327-3328)

\section{Nâkâm:}

Olup sevdâ-y1 Şîrîn reh-nümûnı / Nigâristân k1ldı Bisütûn'1 $\cdots$

Bu dehliz-i fenâ olmuş baña teng / Mekânımdur bu kûh u bu dil-i seng (474-511) ${ }^{56}$

\section{Şîrîn, Ferhâd'a, neden dağı mesken tuttuğunu sorar:}

Ne istersin bu kûh-1 Bisütûn'dan / Ne istersin bu seng-i saht-gûndan

Niçün bu kûh-1 mihnetde zebunsun /Niçün pâ-bend-i kayd-1 Bisütûn'sun (572-573)

Ferhâd, Şîrîn'in geldiği Bisütûn dağından başka rahat ettiği yer olmadığını ifade eder: Ne bir ârâmgâhım var ki anda / Bulup bir lahẓa râhat ol mekânda

\footnotetext{
55 Ayrica bk.: 799, 851.
}

${ }^{56}$ Ayrica bk.: 372-374. 
Beyâbân-gerd idüm vahşiler-âsâ / Makâmım olmuş idi kûh u sahrâ (587-609)

Be-her hafta gelirdüm hâk-i pâye / Bakurdum ba'dden sen tâze aya (611)

Mecnûn ve Ferhâd gibi Cemşîd $\ddot{\boldsymbol{u}}$ Hurşî́ mesnevîlerinin kahramanı Cemşîd de Hurşî̉'e olan aşkı dolayısıyla divaneleşmiş ve dağları mesken edinmiştir. Cemşîd ü Hurşî̀d mesnevîsini, Selmân'dan tercüme ve nazire usulüyle Türkçeye kazandıran şairler, Ahmedî, Abdî ve Cem Sultan'dır. Mesnevîlerde işlenen aşk beșeridir; ancak Ahmedî'nin eseri diğerlerinden farklı olarak tasavvufî̀ tarza eğilmiştir (İnce, 2000: XXXII). Mesnevîlerde, Cemşîd, Hurşîd'i gördükten sonra dağlara düşer:

\title{
Cem Sultan:
}

Çü derd ü gam şehün başına üşdi / Hemân dîvâne bigi tağa düşdi

Çü güm kıldı melik-zâde nigârı / Kılurdı tağ içinde âh u zârı(2813-19) ${ }^{57}$

\begin{abstract}
Abdî:
Tutup aşkile râh-u kûhı fi'l-hâl / Giderdi âh u vâhile ol nigû-fâl

Çeküp Mecnûn gibi kûh içre nâle / Saçı Leylâ'dan umardı nevâle (3678)
\end{abstract}

Ahmedî̀ de, Hurşîd, Cemşîd'e, Ferhâd gibi dağa düştügünü, vatanını terk ettiğini ifade eder:

Vuhûş olmış-1dı anunla dem-sâz / Ana tağda sadâ-y-1dı hem-âvâz

$\cdots$

Niçe kim tağdan çıkardı hurşîd / Varurdı tağ başına râst Cemşîd (2783-85) $)^{58}$

\section{Cem Sultan:}

Çü derd ü gam şehün başına üşdi / Hemân dîvâne bigi tağa düşdi

Giderken tağ içinde gönli gamnâk / Gam-1 hasretle iderdi yakasın çâk (2814-19)

\subsection{Vatan-ı Aslî Olarak "Çöl"}

Âşı̆̆ın doğup büyüdüğü vatanı yerine ikâme ettiği vatanlardan biri "çöl"dür. Vatanın arketipsel mahiyeti, bedenin ve ruhun ait olduğunu hissettiği yeri vatanı olarak görme anlayışını beraberinde getirir. Âşık, varlık olarak ancak sevgiliyi kabul edip onun hayâli ile özgürce beraber olabildiği "çöl”"ü aslî vatanlarından biri olarak seçer. Dişil mekân unsurlarından biri olan çöl, âş̧ı̆ın sı ğındığı, değişip dönüştüğ̈̈ yuvalarından biridir. Âşık burada, sonsuzluk ve hiçlik duygusunu aynı anda yaşar.

Çöl, âşı̆̆ın, ağyardan; hevâdan boşalan kalbinin temsilidir. Canlı ve cansız varlık unsurlarından arınmış olan çöl, âşığın kalp ikliminin dünyevî aksidir. Çöl, kumdan oluşması sebebiyle de âşığın öze dönüşünde bedensel boyutuna dönme meylinin ifadesidir. Topraktan yaratılmış olan insan, ruhanî olarak geldiği öze dönerken bedenî olarak da toprağa döner. Aşk

${ }^{57}$ Ayrica bk.: 2958.

${ }^{58}$ Ayrica bk.: 2546. 
cevherinin kalbi maşuğa çekmesi gibi, toprak da âşığın bedenini aslî yapısına çeker. Esasında maşuk, âşığın bir yansıması, çöl de vatan olarak toprağın bir sûretidir.

Kuraklık, sıcaklık, uçsuz bucaksız olma özellikleri dolayısıyla çöl, kişinin, yiten umudunun bir temsilidir. Uçsuz bucaksız bir kuraklıkta âşığın amaçsızca dolaşması, yolunu kaybettiği hissini verir. "Ayrıca uçsuz bucaksızlık, bir fenomen olarak düşlemenin mekânı, düşleyenin dünya dışına çekildiği yerdir. Uçsuz bucaksızlığın hayale kazandırdıklarıyla saf hayalgücünün saf varlığı gerçekleşmiş olur" (Bachelard, 2017: 223-224).

Çölün görülebilen her noktasının aynı olması, âşığın bir çıkış yolu bulamamasını ifade eder. Ne yöne gitse kuraklık ve sıcaklık, çöl vatanında meskendir.

Kuraklık ve sıcaklık, çölde bulunan "ateş"e münhasır mizaç özellikleridir. Ateş unsurunun kendine mahsus tabiatı sıcak ve kuru olup, mutlak ulvî bulunduğundan, diğer unsurlara zıttır. Çeşitli şekiller almaya kabiliyeti vardır. Ateş; bitki ve ağaçları yakıp kül etme kabiliyetine sahiptir (Erzurumlu İbrahim Hakk1, 1997: 188-189).

Topraktaki varlığıyla bitki unsurlarını yok eden ateş, âşığın kalbinde var olduğunda da onun dışındaki varlıkları ve nefsin arzularını yakıp kül eder. Bu mizaç uyumu, âşı̆̆ı, kendi tabiatına uygun, âteş-tabiat bir mekânı vatan edinmeye zorlar (Sağlam, 2020: 257).

Beyitlerde "çöl”ü ifade için, "sahrâ, deşt ve beyâbân" kelimeleri geçmektedir. Bunlardan "sahrâ", çöl dışında, "kır, ova" (Şemsettin Sami, 1987: 819; Devellioğlu, 2003: 913), manâlarına da gelmektedir. Ancak beyitlerde kastedilen açıkça "çöl”dür.

Leylâ vü Mecnûn mesnevîlerinde çöl, Necd'e giden yolun üzerindedir. Bu nedenle dağ ve çöl sık sık beraber anılır. Mecnûn, her defasında sadece Necd'e değil, çöle de döner:

\title{
Eb̂̂ Bekr el-Vâlibî:
}

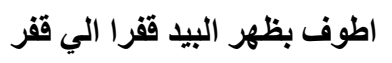

[“Deveye bindim, çöl çöl dolaşıyorum”. Ebû Bekr el-Vâlibî, 1987: 39.]

\begin{abstract}
Nizâmî:
Her gün sabah koşturmaya başlarmış / Başı açık, yalınayak çölde dolaşırmış (923-5)

İnsanlardan uzaklaşan Mecnûn da çölde / Terse dönmüş bahtı gibi dolaşıyormuş çölde $(1557)^{59}$
\end{abstract}

Şâhidî:

Meger kim Hızrıdı hazrâya düşdi / Delürdi derdile sahrâya düşdi (1140)

Beyâbân içre gezinirdi bî-râh / Degüldi kendü kendüzünden âgâh (1166) ${ }^{60}$

\section{Ali Şir Nevâŷ̂:}

Bir yatkanı südrelip şitâbân / Dîvâne kibi tutup beyâbân (1192)

Andın sonğ eşkidin töküp seyl / sahrâ san çün kılur edi meyl (1220) $)^{61}$

\footnotetext{
${ }^{59}$ Ayrica bk.: Nizami, a.g.e., 1066, 1083, 1636, 1898, 2517, 2526-53, 3055, 3086-9, 3251, 3264-66.

${ }^{60}$ Ayrica bk.: 1296-1300, 1453-56, 1714-17, 1721-22, 3645-48, 3836-7.

${ }^{61}$ Ayrica bk.: 1402, 2560, 2722, 2804, 2964-5.
} 


\section{Behiştî:}

bes eyledi geșt-i deșt ü kûhsâr / kalmadı karârı bâd girdâr (1303) ${ }^{62}$

\section{Hamdullah Hamdî:}

Irag oldı çü Mecnûn mâh-1 nevden / Düşüp sahralara dur oldı evden (451-58) ${ }^{63}$

\section{Ahmed-i Rudvan:}

Gehî dîvâneye kûhidi Me’vâ / Gehî âhû bigi tutardı sahrâ (31b)

Ana çün 'Arab'da gösterdi gaddâr / Tutub vahşî bigi bu dahı sahrâ (160b $)^{64}$

\section{Fuzûlî:}

Aşkın yuvası, Fuzûlî'de, Şair'in tabiatının da etkisi ile dağdan daha çok çöl olarak geçer. Şair, çöl için "aşk vadisi” tabirini kullanır. Eserinde Mecnûn'u kendisi ile özdeşleştiren Şair, hayatında elde edemediği imkânları ve aşka temayülü, adeta batıni vatanı olan "çöl”ü sık sık anarak ifade eder (Sağlam, 2020: 260):

Ger gâfil idün ol imdi âkil / Sahrâlara düşme gezme gâfil (2100)

Efgân edüp etdi hırkasın çâk / Sahrâlara düşdi zâr ü gamnâk (1601)

Çölün en fazla anıldığı eserlerden biri de Larendeli Hamdî̀'nin eseridir:

Beyâbânlarda ol turfe gazale / Sürer üştür idüb feryâd u nâle (1088) ${ }^{65}$

\section{Andelîb:}

Mecnûn boynundaki zinciri koparıp çöllere gider:

... çöllerde gerdesinde vahşī... (s.90)

“... andan song Mecnûn-ı dil-efkâr bu sözlerni aydıp yüz ferr-i beyâbânğa bartp âh u efğân tartıp ısık kumlarnı başı̆̆a saçıp durur, kûh-be-kûh deşt-be-deşt çarh urup yürür irdi”. (s.84)

Saydıng koyaber, sayyâd dil-pâre iken men dek

Çöllerde gezip yürgen seyyâre iken men dek (s.85-86) ${ }^{66} 67$

\footnotetext{
${ }^{62}$ Ayrica bk.: 1303-9, 1319-20, 1325-42.

${ }^{63}$ Ayrica bk.: 451-58, 1789, 1798, 2608-10, 2620, 3146, 3784-6.

${ }^{64}$ Ayrica bk.: 94b, 102b, 116b, 122a.

${ }^{65}$ Ayrica bk.: 2505, 2536, 2546, 2576, 2596, 3325.

${ }^{66}$ Ayrıca bk.: s.31-32, 52, 54, 62, 88, 90, 93, 98, 103, 119-120.

${ }^{67}$ Dihlevî için bk.: Dihlevî, 1964: s.90; Câmi için bk.: Camî, 1313: 3, 28; Süheylî için bk.: Abdel-Maksoud, 2004: 113; Hâtifî için bk.: Levend, 1959: 79; Celîlî için bk.: 488, 494-507, 822-3, 947-49; Sevdâyî için bk.: 382-84, 567-81, 756; Hakiri için bk.: Solak, 2003: 126b/13, 152b-2, 152152b/09-10, 156b/4164b/8, 164164b/ 11, Celalzade Salih için bk. Kütük,
} 
Hüsrev ü Şîrîn mesnevîlerinde Ferhâd, dağ ile birlikte çölü de vatan edinmiştir. Nitekim bazı beyitlerde bu iki mekân beraber kullanılır:

\section{Nizâmî:} 2012: 229).

"Şaşkınlıktan dă̆ ve sahra yolunu tutmuş, iniltisi dăg ve sahraya yayılmıştı.", (Nizâmî, 232).

"Sonra yine sahra yolunu tutar, kendini sevgilisinin gamına bırakırdı.", (Nizâmî, 2012:

"Sevda aklını öyle sarmış ki, o sevda yüzünden sahra yolunu tutmuştu. O dilberin güzelliğine olan aşkından, gece-gündüz baş açık, yalınayak dolaşmaktadır.”, (Nizâmî, 2012: 232).

Kutb:

Uş andın tuttı ol sahra yolını / Akıtu çeşme tig közler bulını (416)

Köyüp bağrı ödükde ingreyü zâr / İkinçi yol tutup sahraka kiter (2472)

\section{Şeyhî:}

tolup sevdâ buhârından dimağı / kodı şehri vü tutdı deşt ü tağı (4380)

gèrü ol secdeden ser-mest ü şeydâ / turup tutardı deşt ü tağ u sahrâ (4414)

\section{Ahmed-i Rudvan:}

O sahrâda k1lurken seyr-i reftâr / Bu şi’ri söylenüb ağlar idi zâr (2183)

\section{Sâlim:}

Feryâd ederek o dil-perîşân / Tutdu reh-i vâdî-i beyâbân (2813)

Mecnûn gibi düşdü deşt ü tağa / 'Âr eyledi 'aşkdan firâğa (2816)

Ferhâd ü Şîrîn mesnevîlerinde de Ferhâd, çölü mesken edinir:

Ali Şir Nevâyî:

Çıkıp eyler idi ol tağnı geşt / Mutâfî irdi gâhî tağ u geh deşt (BE 55 $5^{\mathrm{b}}$ 16)

\section{Lami' $\hat{\imath}$ :}

Gehi seyrân-1 kûh u deşt eyler / Nesîm-âsâ gehî gül-geşt eyler (3406)

1995: 727-31, 890- 895, 1996, 2057; Halife için bk.: Levend, 1959: 303; Atâyî için bk.: 7b, 9a, 19a, 19b, 47a; Örfi için bk.: 135, Nâkâm için bk.: s.4,13, 21, 26, 32, 38, 49, 50, 64, 79, 81, 85, 89, 106, 112-113, 120, 218. 


\section{Şâhî:}

Yüz urup kūh u deşte âb gibi / Sürinür ya'ni gird-bâd gibi (3925)

\section{Nâkâm:}

Vuhûş-âsâ tutup râh-1 beyâbân / Vuhûş ile gezüp hayrân u nâlân (359)

\section{Hüsrev'in nâdimleri, Ferhâd'ın Leylâ'ya olan aşkından çölleri mesken tuttuğunu ifade ederler:}

Yakupdur nâr-1 'aşka hânumânın / K1lupdur kûh u sahrâda mekânın (371)

Kılup sahrâ tarikin bâz der-piş / Gidür sahrâlara giryân ü dil-riş (373) ${ }^{68}$ düşmüştür:

Cemşîd $\ddot{\boldsymbol{u}}$ Hurşîd mesnevîlerinde, Cemşîd, Hurşî̀d'in aşkından dağ ile birlikte çöllere de

\section{Abdî:}

Sihâb-1 dideden geh kûha bârân / Saçup sahrâda seylâsâ şitâbân (3690)

Gezerdi kûh san Ferhâd-1 gamgîn / Yürür sahrâda san Mecnûn-ı miskin (3721)

Ahmedî̀' de, Mihrâb, Cemşîd'i çölde bulur:

Gözi hasretle girmiş-idi gâra / Akıdur çeşmeler ol kûh-sâra (2845)

\section{Mihrâb, Cemşîd'e dağ ve çölde yaşamanın ona göre olmadığını ifade eder:}

Kamu esbâb çün olmış müheyyâ / Ne gerekdür sana bu hûh u sahrâ (2934)

\section{Cem Sultan:}

Giderdi mihnet ile zâr u şeydâ / Görinmezdi gözine tağ u sahrâ (2817)

\subsection{Vatan-ı Aslî Olarak "(Viran) Mağara"}

Aslî vatan unsuru olarak seçilen vatanlardan biri "mağara"dır. Mağara, dişil mekânlardan olup dünya üstü özden kaynaklanan vatan duygusunun arketipsel bir fenomenidir. Âşı burada, uzlet hâlindedir ve yeniden doğma sürecine girer.

Bahsi geçen mesnevîler içinde, mağaranın tavattunu, Leylâ vü Mecnûn mesnevîlerinde görülür. Mağara, dağın içindedir. Mecnûn, Necd'in içinde bir mağarada yaşamaktadır. Onun aşk sığınaklarından biri mağaradır. Mağara, dağın içinde, adeta bir çile mekânıdır. ${ }^{69}$ Mağara, dar ve alçak bir mekân olarak, sâlikin, etrafındaki evrâdlara (nesne / eşya) dikkat vermesini engeller. Etrafını seyr

${ }^{68}$ Ayrica bk.: 377, 385, 612, 652.

${ }^{69} \mathrm{~Hz}$. İbrahim bir mağarada doğmuş̧tur. Hz. Peygamber (s.a.s), bir mağarada uzlete çekilmiştir. 
edemeyen sâlikin iç gözü açılır ve nefsinin tanımadığı noktalarını keşfe başlar. ${ }^{70}$ Nefsin tanınması, kalbin ilme ermesine, her nefs mertebesi arasında bulunan yetmiş bin perdenin kaldırılmasına imkân sağlar veya perdelerin açılması, marifetünnefsi sağlar.

Âşığın vatanlarından bir vatan ve bir aşk yuvası olan mağara, dönüşümün merkezini temsil eder. Cehennem vatanının dünyadaki sûretlerinden biri olan kuyu ${ }^{71}$, hikâyelerde mağara ${ }^{72}$ olarak yer alır. Burada vaktin ve vatanın içinde Âşsk, aslında kendi "kuyu"sundadır. ${ }^{73}$ Bu kuyu, onun batınî olarak düştüğü en dip noktanın zahiri bir yansımasıdır. "Her zorlukla beraber bir kolaylık" (İnşirah, 94/5) olmas1, her kolaylık / bast / genişlikten önce bir zorluğu / kabz / darlığ1 şart koşar. ${ }^{74}$ Genişlik / ferahlık veya marifetünnefs, bu darlığın bir ödülüdür (Sağlam, 2020: 262).

Mağara, "Rahîm" isminin tecellîgâhıdır. "Merhamet" ve merhametle bağlantılı olarak "koruma" manasındaki rahîm, dişildir ve kadına özgüdür. Doğum, Âdem ve Havva'dan, Havva'ya verilmiş bir özelliktir. Dişil form olan mağara -çünkü sakl olan her şey dişidir- (Bachelard, 1995: 51) kuşatır, sarar, büyütür ve doğum için gerekli seviyeye gelinmesini sağlar. Mağaraya girmeyi reddeden veya korkan kişi, kendi ölümü ve dolayısıyla doğumunu da görmeye istidadı olmayan kişidir. Dişil mizacı ağır basan Mecnûn'un istidadı, onu bu ürkütücü mekânlara ait korkudan alıkoyar (Sağlam, 2020: 262).

Zaman zaman Leylâ vü Mecnûn mesnevîlerinde anılan virane; zayıflamış, harab olmuş nefsin bir temsili olarak da düşünülebilir. Aşkın viran ettiği nefsin sahibi, kendi gibi bir virane / harabe içinde bir hayat sürmektedir.

Leylâ vü Mecnûn hikâyelerinde, Âşık'ın mağarada yaşaması, ilk eserden itibaren diğer mesnevîlerde de yer alır. Bazı mesnevîlerde, babası tarafindan aranan Âşık, "virane bir mağarada" bulunur. Burada, mağaranın virane ve harap olması özellikle vurgulanır. Âşık’ın viran hâlinin yansıması olan viraneler, onun düştüğü kuyunun türü olarak sadece bir mağara değil, viran bir mağaradır (Sağlam, 2020: 262).

\section{Ebû Bekr el-Vâlibî:}

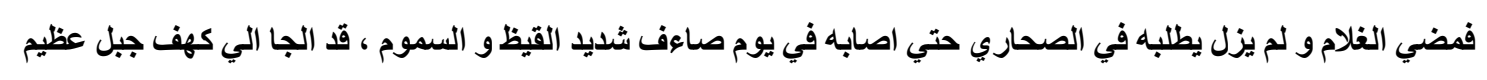

[“Genç adam kalktı ve çölde aramaya başladı, onu çok sıcak, kuru ve sıcak rüzgârla dolu bir günde buldu, büyük bir dağın mağarasına sığınmıştı”. Ebû Bekr el-Vâlibî, 1987: 97.]

\section{Nizâmî:}

Hiç çekinmeden her mağaraya bakmış / Her tarafta çılgın oğlunu aramaya çıkmış $(1260-65) \cdot{ }^{75}$

Onu darackk bir köşede yatarken görmüş / Düşmüş, başını taşa koymuş uyurken görmüş

\footnotetext{
${ }^{70}$ Organların istidadlarını dış dünyadan çekip içe yöneltmesi, sülukun özelliklerinden biridir. Bu süreç, bedenî ihtiyaçları giderme temayülünün mümkün mertebe azaltılması ile mümkün olur. Böylece, beden zayıflar, kalp güçlenir ve batıni bilgiyi elde edecek seviyeye ulaşır.

${ }^{71}$ Jung'un düşünce sistemine göre, kuyu / mağara, Cehennem arketipinin dünyevi bir formudur. Ateş, kötü vasıfların ölümünü sağlar. Böylece, iyi vasıfların doğumu gerçekleşir. Esasen Cehennem de bir cezadan çok, arınma mahallidir.

72 "Moğolların mitsel kıralı Kesar, öte dünyaya kabul imtihanı olarak dağların tepesinde yer alan bir mağaradan girmişlerdir; şamanın cehenneme inişi de aynı şekilde bir mağara sayesinde olmaktadır.” Eliade, 2018: 60.

${ }^{73}$ Her sâlik, bir "kuyu" vatanından geçmek zorundadır. Hikâye içindeki en dar mekân olan mağara, Kahraman'ın kuyusudur.

${ }^{74}$ Her cehennemden sonra bir cennet şeklinde de anlaşılabilir. Cennet ve cehennem, bu suretlerin aslı veya arketipidir.

${ }^{75}$ Ayrica bk.: Nizami, 2013: 1906-9, 2146-7.
} 


\section{Şâhidî:}

Meger ol genç künc-i gâr içinde / Yaturdı halka olup mâr içinde (1583)

Ki tutmış anda bir gâr içre mesken / O gârı eylemiş âhıla külhan (2795-99)

\section{Hamdullah Hamdî:}

Perî gibi yürürken buldı bir gâr / Girüp kıvrıldı yatdı nitekim mâr (1791)

\section{Ahmed-i Rudvan:}

Nazar kıldukda gördi bir mağâra / Ser-â-ser yolları pür-seng-i hare (68a)

Çün irişdi şebüñ dûd-1 siyâhı / Yitişdürdi anı bir ğâra râhı

Karâr itti gice ol ğâr içinde / Sabâh olınca yatdı mâr içinde (83a)

\section{Larendeli Hamdî:}

Yiridür kûh-1 Necd evcinde bir gâr / Ki taşdur bâlisi vü bisteri hâr (1398)

Teb-i gam iki kat itmiş nihâlin / Yumuş eşgi ruhi verdinün alın (1411-15) ${ }^{76}$

\section{Andelîb:}

Mecnûn, Leylâyı beklediği bir gün mağaraya girip yatar:

“... yine bir ğârğa girip nâle feryâd birle bir post üstühª̂n bolup yatdı”, (s. 98). ${ }^{77}$

\subsection{Vatan-ı Aslî Olarak "Sevgilinin Kûyu"}

"Mahalle, köy, yurt, sokak" (Pala, 2012: 280) manâsındaki "kûy", divan şiirinde sevgilinin oturduğu yerdir. Âşık için, sevgilinin kûyu, diğer tüm mekânlardan üstündür ve "Kâbe" ile özdeşleştirilir. Mümin için dünyanın merkezi Kâbe olması, âşık için de sevgilinin kûyudur. Merkez unsur, doğası gereği sâbit, etrafındaki unsurlar ise bu merkez karşısında seyyârdır. Bu itibarla âşık, sevgilinin kûyunu Kâbe gibi devamlı tavaf hâlindedir.

Vatanın imgesel varlığı gereği, Allah'ın görüleceği mekân olan el-Kesîb'in bir sûreti sevgilinin oturduğu dağ olduğu gibi, aynı zamanda yakın mesafede de onun kûyudur. Âşık için, sevgilinin mekânın aslî vatan unsuru olarak benimsenip Kâbe ile özdeşleştirilmesinin temelinde bu arketipsel mahiyet vardır. Âşık, aslî vatan unsuru olan sevgilinin kûyundan ayrılmak istemez ve çeşitli vatan-1 seferîlerde bulunduktan sonra yine oraya gelir. Bu durum, sevgilinin sâbit, âşığın, âşıklık hissiyatı gereği seyyâr olmasındandır.

Âşık, maşuğun cemâlini görmeden duramaz. Onun cemâlini görme şevki, onu sürekli maşuğun yakınına çeker. "Bu durumda, âşığın kendisi maşuğun hüsnüne maşuktan daha yakındır;

\footnotetext{
${ }^{76}$ Ayrica bk.: 1561, 1999-2000, 2038, 3094-3102.

${ }^{77}$ Dihlevî için bk: 1964: s.150; Camî için bk.: 1313: 25; Mektebî için bk.: Levend, 1959: 60, 67; Celîîi için bk.: 487; Celalzade Salih için bk.: 743-51.
} 
zira maşuk, kendi hüsn ve cemâlinden onun vasıtasıyla beslenir. Şüphesiz âşık, maşuğa onun kendisine olduğundan daha yakın olmaktadır" (Ahmed Gazali, 2019: 35). Bu nedenle, âşık, her firsatta sevgilinin kûyunu ziyaret etme temayülü gösterir. Genellikle "hayret" ile sonuçlanan ziyaretlerde âşık, elinde olmadan tekrar diğer vatan-1 aslîleri olan dağ, çöl ve mağaraya döner.

gider:

Leylâ vü Mecnûn mesnevîlerinde Mecnûn, rakipten bulduğu her firsatta Leylâ’nın kûyuna

\section{Ebû Bekr el-Vâlibî:}

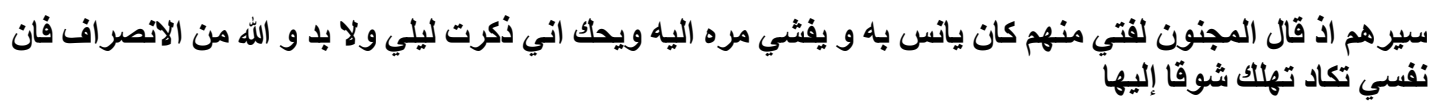

[“... Onlar yürürken, Mecnûn güvendiği ve sırrını anlattı̆̆ı gencin birine dedi ki: Sakın! Ben Leylâ’yı hatılladım ve vallahi gitmem gerekiyor, çünkü benim içim ona hasretten öldü ölecek”, (Ebû Bekr el-Vâlibî, 1987: 74)].

\section{Nizâmî:} $(981)^{78}$

Artık gönlüne söz geçirememiş, âciz kalmış / Sarhoş olup sevgilinin çadırının içine dalmış

\section{Cami:}

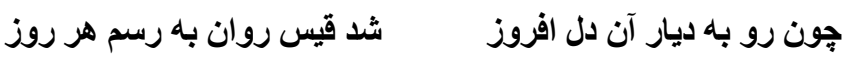

[“Kays her günkü gibi Leyli ile buluşmak için onun diyarına gider”, [Cami, 1313: 16]. ${ }^{79}$

\section{Şâhidî:}

Dahi gayrı yere çün bulmadı yol / Yüridi kûy-1 Leyli’den yaña ol (1241)

\section{Ali Şir Nevâyî:}

Leylî haşemiga çün yavuştı / Tüşti anga he ne iş ki tüşti (1162)

Mecnûn savaştan sonra göçmüş bulunan Leylâ'nın kabilesinin mahalline gider ve gamlanır:

Kim yetti çü ol dimenga Mecnûn / Kim seyre tip erdi mihr-i gerdûn (2038-80)

\section{Hamdullah Hamdî:}

Tavâf-1 kûy-1 yâre gitdi san peyk / Safasından diyüp lebbeyk lebbeyk (621-25) $)^{80}$

\footnotetext{
${ }^{78}$ Ayrica bk.: 1995.

${ }^{79}$ Camî'den yapılan alıntılar için bk.: Câmî (1313), Leylî vu Mecnûn, (Haz.: Vâhid-i Destgirdî, 2016), Tahran.

${ }^{80}$ Ayrica bk.: 1888-9, 2359-63.
} 


\section{Ahmed-i Rudvan:}

Olurdı her nefes anlara hem-râh / Giderdi kûy-1 yâre her sehergâh $(27 a)^{81}$

\section{Fuzûlî:}

Azm eyledi hâk-i kûy-1 yâra / Leylînün evi olan diyara (1159) ${ }^{82}$

\section{Mecnûn, Leylâ'nın sarayına su yolunu takip ederek gider:}

\section{Mektebî:}

“Mecnûn, mağarada, Leylâ'nın sarayına giden bir su yolu bulur. Yolu takip ederek Leylâ'nın sarayına varır", (Mektebi için bk.: Levend, 1959: 67).

\section{Mecnûn, geceleri sevgilinin kûyuna gider:}

\section{Nizâmî:}

Her gece özlem dolu şiirler okuyormuş / Gizlice sevgilinin sokağına gidiyormuş (927)

\section{Cami:}

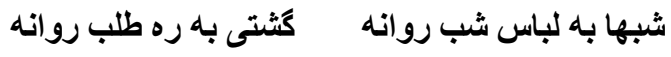

[“Geceleri özleme bürünüp Leyli’nin yolunu tutardı.”, s.17.]

\section{Celalzade Salih:}

Bolsa ger kuş olub uçaridi / ‘Azmi çünkim diyar-1 yaridi

Giceler zar u zar içlerdi figan / Hem gider hem diridi bunı revan (895-905)

Mecnûn, sevgilinin kûyuna çeşitli bahanelerle, çeşitli şekillerde gider. Bunlardan biri, yemek dağıtan Leylâ'dan, herkes gibi yemek almaktır. Âşık, rakipten korkusu nedeniyle zaman zaman tebdil-i kıyafete girer:

\section{Hakîrî:}

Aldı ol dem daşa vurdı kâsesin / Oldı handân anda Mecnûn-ı hazîn

Bir zemân yârın katında durdı ol / Bu bahâne-y-ile yârın gördi ol (153153b/ 09)

\section{Celîlî:}

Tebdîl idüben libâs-1 pâki / Egnine salar palâs-1 çâki

Bahş olur iken ta 'âm nâsa / Mecnûn hem irişdi sundı kâse (1577-79)

\footnotetext{
${ }^{81}$ Ayrıca bk.: 94a, 95b.

${ }^{82}$ Hatifi için bk.: Levend, 1959: 80; Celalzade Salih için bk.: 1724-69; Atâyî için bk.: 6b-7a; Nâkâm için bk.: s.65.
} 


\section{Sevdâyî:}

Mecnûn işidüp bu hâli geldi / Hem eline bir çanağı aldı

Maksûdı degül kim aş alaydı / Geldi Leyli'nün yüzin göreydi (986-91)

\section{Celalzade Salih:}

Aldı kendüsi tahtasın anun / Haberi olmadın o cananın

Bu bahaneyle gördi cânânın / Bir nazar anun itdi seyrânın (549-61)

Kays, Leylâ’yı görmek için çeşitli bahanelerle onun oturduğu evin etrafında dolaşır. Hatta okula dahi Leylâ'yı görmek bahanesiyle gelir:

Sebebin sanma gayre meyliyidi / Bil ki derdi cemâl-i Leyli'yidi $(562-67)^{83}$

\section{Mecnûn, kimi zaman esir / köle kılığnda Leylâ'yı görmeye gider.}

\section{Nizâmî:}

Uzaktan bir kocakarı çıkmış meydana / Yanında bir çılgın, geliyormuş o yana ...

Bağladıktan sonra okşamış Mecnûn'u / Boynunda iple götürüyormuş Mecnûn'u (1998-2049)

\section{Şâhidî:}

Çü buldı pîre-zen bu hôş şikârı / Şimârınuñ görindi râst-gârı

Alub boynundan ol şahsuñ kemendi / Bırakdı gerden-i Mecnûn'a bendi (2453-2503)

\section{Hamdullah Hamdî:}

Meger gördi gelür bir pîre 'avret / Bile bir şahs var dîvâne hey'et

Didi Mecnûn düşüp pâyına fill-hâl / Bana tak bagı boynından anun al (1893-1940)

\section{Ahmed-i Rudvan:}

Didi âzâd idüb bu derdümendi / Benüm boynuma dak zencîr ü bendi

Ki ben zencîre lâyık derdmendem / Bugün dîvâneyem hem müstemendem (86b)

Fuzûlî̀' de, esiri gezdiren kocakarı değil, yaşlı bir adamdır:

Mecnûn dedi sehv edüpsen ey pîr / Dîvânelere gerek bu zencîr ...

Zencîre girüp remîde Mecnûn / Erbâb-1 cünuna düzdi kânûn (1616-1623) ${ }^{84}$

\footnotetext{
${ }^{83}$ Hatifi için bk.: Levend, 1959: 78-79; Halife için bk.: Levend, 1959: 303-304; Örfi için bk.: 137-151.

${ }^{84}$ Larendeli Hamdî için bk.: 2744; Atâyî için bk.: 24a-24b; Nâkâm için bk. 2007: s.66.
} 
Mecnûn, hilesinin tuttuğunu anlayınca, ikinci kez kılık değiştirerek Leylâ'nın kûyuna gider:

\section{Celîlî:}

Bir gün dagı ol fesâne-perdâz / Eyler yine bir bahâne âgâz

...

Leylî göricek gedâ-yı kûrı / Dir mâderine k’ey dîde nûrı (465-77)

\section{Celalzade Salih:}

Tutdı bir gün dahi gedâ şeklin / Ne gedâ merd-i bî-nevâ şeklin (700-13)

\section{Larendeli Hamdî:}

Gelüb Mecnûn'a hoş bu resme hâlet / Dem-â-dem kendüye idindi cadet

Ki girüb dürlü dürlü şürete tâ / Gedâ gibi ider her sü temannâ (2800-1)

\section{Mecnûn, esir / köle kılığından başka, kör dilenci kılığına da girer:}

\section{Hâtifí:}

“Bir gün kör dilenci kılığına girerek Leylâ’ya gider. Leylâ’nın kapısına gelince değneğini vurarak yere düşer” (Levend, 1959: 79).

\section{Hamdullah Hamdî:}

Bahane iyleyüp Mecnûn-1 rencûr / Gözin bağladı bir gün nitekim kör

Çü Mecnûn'ı bu hile iyledi şâd / Yine bir dürlü âle itdi bünyâd (430-48)

\section{Ahmed-i Rudvan:}

Gözin yumub cihândan öynürdi / Görenler anı nâ-bī-nâ sanevber

'Asâ aldı eline sürdi gitdi / Diyâr-1 Leyli'ye ol demde yitdi (30a)

...

Gedâlar biñ şeklini düzetdi / Varub Leylī diyârını gözetdi (30b-31a)

\section{Fuzîulî:}

Bir gün dahi ol behâne-perdâz / Bir özge behâne kıldı âgâz ...

Takrîb ile azm-i yâr kıldı / Leylî evine güzâr kıldı (1680-83)

${ }^{85}$ Celîlî için bk.: 452-59; Hakiri için bk.: Solak, 2003: 122a/12; Sevdâyî için bk.: 365-70; Larendeli Hamdî için bk.: 278688; Celalzade Salih için bk.: 681-713. 
Bir başka sefer, koyun postuna girerek Sevgili’nin kûyuna gider:

Mektebî:

"Mecnûn, bir gün İbn-i Selam'ın sürülerine bakan çobana yalvarır; koyun postu giyerek sürü ile birlikte Leylâ’nın çadırı önüne gelip derdini döker" (Levend, 1959: 68).

\section{Halife:}

“Onu giyerek sürüye karışıp Leylâ’nın diyarına gider” (Levend, 1959: 304).

\section{Mecnûn'un girdiği kılıklardan biri de derviş kılığıdır:}

\section{Hamdullah Hamdî:}

Meger Mecnûn o gün sûret degişdi / Varup derviş̧ler içre karışdı (2904)

\section{Celîlî:}

Tebdîl ider kamu libâsın / Egnine alur gedâ pelâsın

Leylî göricek görür ki dervîş / Dil pür-gam u dîde nem-ciger rîş (466-71)

\section{Hakîrî:}

Girdi bir gün Kays dervîş donuna / Vara ol kisvetle Leylî yanına (122a/12)

Hüsrev ü Şîrîn mesnevîlerinde Ferhâd, Şîrîn'in sarayını gözetler:

\section{Nizâmî:}

"Her hafta o huri yüzlünün misafiri olur, fakat uzaktan yüzünü görmekle kanaat ederdi. ... Akşamleyin bir av gibi gelir, o havuzdan zevkle süt içerdi. ... Dolaştığ yer de yalnız o havuzun etrafi idi. Geceleri havuzun etrafindan ayrılmaz, bütün gece etrafinda dolaşırdl.", (Nizâmî, 2012: 232).

Kutb'da Ferhâd, Bîsütûn üzerinden sevgilinin sarayına bakar:

Kilür her hefte tîz yügrü yügrü / Turur kol kavşurup karş1ka ötrü

Selâm aytıp sürer toprak yüzinge / Kılur ol yir kumın sürme közinge (2482-83) ${ }^{86}$

\section{Ahmed-i Rudvan:}

Diyârını dem-â-dem yürinürdi / Sarâyını ırakdan çevrinürdi $\cdots$

Çü yoğ idi şurû'ı lehv ü lu’be / Tavaf eylerdi kasrını çü Ka'be (2107-13)

Lami'î̀nin Ferhâd u Şîrîn mesnevîsinde Ferhâd, Şîrîn'i gördüğü dağı adeta kutsar:

Bu tağdan ger toğa o subh-1 ümmîz / Zihî mi'râc-1 kadr u 'îd-i câvîd ...

\footnotetext{
${ }^{86}$ Ayrica bk.: 2469.
} 
Yüzin çün kıble kûyın Ka’be bildüm / Bu tağ üstinde cândan vakfa kıldum (2865-66)

Şâhî̉nin Ferhâd-nâme'sinde, Ferhâd, Şî̂n'i görmek arzusu içine düştükçe kalenin etrafinda döner:

Kal'ayı devr iderdi hasretle / Âh u zâri iderdi hayretle (3751)

\section{Ferhâd, her gece, Hüsrev tarafından hapsedildiği kuyudan çıkıp kaleye gider:}

Çâhdan her gice iderdi hurûc / Burc-1 hurşîde eyler idi 'urûc

Eyleyüp kūy-1 dil-berini tavâf / Kal'ayı itdi Ka'be gibi tavaf (3680-3682) $)^{87}$ söyler:

Sevgilinin kuyunu terk etmesini söyleyen Hüsrev'e Ferhâd, orayı Ka'be bildiğini

Didi terk eyle kūy-1 cânânı / Didi kim Ka’be kıldı cânânı (3455)

Cemşî́d ü Hurşîd mesnevîlerinde Hurşîd, annesi tarafından bir kaleye kapatılır. Cemşîd, onu görmek için kaleye gider:

\section{Selmân-ı Savecî:}

"O gece Melik de kapıdan dağa doğru yola çıktı." (713)

\section{Abdî:}

Suyı tolaba ol serv-i sehî-kad / Çemân su gibi akdı olup perî-had

Hemânâ delv kıldı bruc-1 hurşî̀d / Anunla tâ ide bahtını câvîd (4322-23)

\section{Cem Sultan:}

Melik çün çıkıban Hurşîd'i gördi / Dil ü cândan ayağına yüz urdı (3279-84)

\section{Ahmedî:}

Düşüp ayağına eyle ki sâye / Yüzini hâk eyledi ol aya (77-92)

\subsection{Vatan-1 Aslî Olarak "Sevgilinin Kabri”"}

Âşıkların, tuttuğu vatanlardan dağ, çöl ve mağaraya ek olarak Mecnûn, ölümü ile sevgilinin kabrini de vatan tutar. Leylâ'nın ölümünden sonra sık sık ziyaret ettiği kabir, Mecnûn'un tuttuğu son vatan olur. Mecnûn, Maşuk'un kabrinde can verir.

Kabir vatanı, diğer mesnevîlerde olmayıp Leylâ vü Mecnûn mesnevîlerinde görülür. Mecnûn, Leylâ'nın vefatını duyar duymaz soluğu onun kabrinde alır. Çoğu mesnevîde burası, onun son vatanı olur:

${ }^{87}$ Ayrica bk.: 3362, 3709-3711, 3751, 3985, 3927, 3990. 
Ebû Bekr el-Vâlibî:

ثم إنه كان يأوى إلى قبر ليلى ويدور نهاره حتى

[“Sonra Leylâ’nın mezarına gitmeye başladı, orada kalıyordu.”, s.103.]

Nizâmî:

Kâh Leylâ’nın kabrini kıble yapıyormuş / Kâh yaban eşeğinin peşinden koşuyormuş (3544)

\section{Şâhidî:}

Bu halk içinde kim olmışdı pest / Yerinden sıçradı Mecnûn ser-mest

Salub lahdine özin düşen berdüş / İrüb itdi habîbini der-âgûş (5383-4) ${ }^{88}$

\section{Dihlevî:}

مجنون زميان انجمن جست و اقتاد بلخمة لحد يست

[“Mecnûn yaslıların ortasından kalktı ve kendini o kabre attı", s.256.]

\section{Hamdullah Hamdî:}

Bu hâletde olup âvâre gitdi / Varup âhır mezâr-1 yâre gitdi

Sürünü sürünü yüz üzre çün mâr / İrüp kucdı mezârı nitekim yâr (3789-3828)

\section{Ahmed-i Rudvan:}

Gidüb ta'cîlile kabrine yitdi / Giyâhı ter bigi türbinde bitdi (161a)

\section{Fuzûlî:}

Kabrini kucakladı nigârun / Cân sadkası etdi ol mezârun (2993)

\section{Larendeli Hamdî:}

Götürüb şöyle kim eşk-i revanı / Bırakdı ravza-1 Leylî'ye anı ...

Şu resme kocdı varub ol mezâr1 / Ki nakş itdi ruhâmini cizârı (5211-13) ${ }^{89}$

\section{Mecnûn, Leylâ'yı hatırladıkça, onun kabrini ziyaret eder:}

\section{Nizâmî:}

Ağlayıp inlemekten harab ü bitab düşünce / Harekete geçermiş sevgili aklına düşünce

\footnotetext{
${ }^{88}$ Ayrica bk.: 5390.

${ }^{89}$ Süheylî için bk.: Abdel-Maksoud, 2004: 115; Mektebî için bk.: Levend, 1959: 73; Sevdâyî için bk.: 1216-17; Hakiri için bk.: Koçak, 2006: 165165b/ 11; Andelîb için bk.: Evnak, 1378: s.125.
} 
Dağdan sel misali düze akarmış / Leylâ'nın istirahatgahına koşarmış (3532)

\section{Hamdullah Hamdî:}

Gehî 'azmı mezâr-1 yâre oldı / Vuhûş ile gehî âvâre oldı (3843)

\section{Ahmed-i Rudvan:}

Zarûrî derdile 'azm itdi geşte / Gine kasd eyledi tağıle deşte (152b)

Andelîb'de, Mecnûn her gün Leylâ'nın kabrine gelip Fatiha okur:

"Günde barıp Leylīning mezârığa yüzüni sürtüp nevha zârı kılur irdi ve yine du'â Fâtihalar k1lıp yığlar irdi”. (s.125)

\section{Mecnûn, Ferhâd ve Cemşîd'in Vatan-ı Seferîleri}

Âşık, aslî vatanı olarak benimsediği dağ, sevgilinin kûyu, çöl, mağara ve sevgilinin kabirlerine, birtakım vatan-1 seferîlerde bulunur. Âşığın vatan-1 seferîleri, genellikle onun zoraki olarak götürüldügü yerleri kapsar. Vatan-1 aslîler gibi, bu vatan-1 seferîler de Mecnûn'un bulunduğu vatanlardır. Bunların en dikkat çekici olanları; baba ocağı, Kâbe, sevgilinin kûyu, maşuğun kabri ve anne-babanın kabri'dir. Bu vatanlar, büyük oranda yalnızca âşıkların şahı Mecnûn'un vatanlarıdır. Sevgilinin kûyu ve maşuğun kabri aslî vatanlar arasında yer almasına rağmen, dağ ve çöl söz konusu olduğunda seferî vatan konumuna düşer. $\mathrm{Bu}$, âşıkların sevgilinin mekânında "hayret"e kapılmalarından kaynaklanır.

\subsection{Vatan-ı Seferî Olarak "Baba Ocağı"}

Âşı ğın ilk bulunduğu; doğduğu, ikâmet ettiği ve ilk olarak terk ettiği mekân "baba ocağı"dır. Baba ocağı, onun, dar çerçevedeki ilk vatanıdır. Âşık, bu vatan içinde dünyaya geldiğinde huzursuzdur. Huzursuzluk hâlinin arayışa itmesi sonucu, ruhen ait olmadığı vatan, onu, burayı terk etmeye zorlar. Aslî olarak kendine yeni mekânları vatan edinen âşık için, burası vatan-ı seferî olmaktan öteye geçemez. Zorla getirildiğinde ise, bir şekilde aslî vatanlarına tekrar kaçar.

Leylâ vü Mecnûn mesnevîlerinde eve getirilen Mecnûn, evde daha fazla sabredemeyerek her defasında aslî vatanları olan dağ ve çöle geri döner:

\section{Şâhidî:}

Bir iki gün ol anda kâm ü nâ-kâm / Belâ vü mihnetile dutdı ârâm

Pes idüp girü sabrı yerden çâk / İrişdi kûh-1 Necd'e cüst ü çâlâk (1985-87)

Nevâŷ̉' de, Mecnûn, zincirlerinden kurtulup aslî vatanı olan çöle döner:

bir deştka ketti ol mekândın / kim katci i yırak edi gümândın (1402)

\section{Hamdullah Hamdî:}

Turup çâk itdi bir gün perde vü pôst / Düşüp Leylî yolına na'ra-i dôst $\cdots$ 
Elinde seng ü âhen ayağında / Tolup vecd ile ol Necd'ün tagında (1134-6)

\section{Nâkâm:}

Nəşimə neylədi möhnət hasarın

Müsəxxər eylədi vəhşət diyarın (s.32) ${ }^{90}$

Abdî̀nin Cemşîd $\ddot{\boldsymbol{u}} \boldsymbol{H}$ Hurşîd' inde Mihrab, Cemşîd'e, baba ve ana ocağını terk ettiğini ifade eder. Terk edilen ev, vatan-1 seferîdir:

Vatandan gurbet oldı sana muhtâr / Pederler mâder itdün şöyle bî-kâr (1817)

\subsection{Vatan-ı Seferî Olarak "Kâbe"}

Mümin için aslî vatan unsurları arasında olan "Kâbe", âşı için seferî vatan unsurlarındandır. Bunun nedeni, onun Kâbe yerine, merkezî; aslî vatan unsuru olarak "sevgilinin kûyu"nu ikâme etmesindendir. Vücudun merkezî konumundaki kalp, maşuğu tek varlık olarak benimsediğinde, onun mekânını da aslî; merkezî vatan olarak benimseyecektir. Âş̧1 için bu nedenle, inancı çerçevesinde önem atfettiği Kâbe dahi, ikincil vatan unsuru durumunda olup vatan-1 seferî konumundadır. Mecnûn, babası tarafından zorla getirildiği Kâbe'den kaçıp tekrar dağ ve çöle döner:

\section{Ahmed-i Rudvan:}

Bitürdiler çü hac emrin yirine / Dönüb ‘azm itdiler yirlü yirine

İrişdiler kamusı menziline / Gine Mecnûn dahı geldi iline (46a)

\section{Fuzûlî:}

Ol pîr kalup orada hayrân / Mecnûn dutuben reh-i beyâbân (1134)

\section{Nâkâm:}

Kabe'den dönen Mecnûn'un aşkı artmıştır. Mecnûn, tekrar çöllere düşer:

Tutub Məcnun yenə rahi-biyaban / Biyabangərd oldu Leyliguyan (s.26) ${ }^{91}$

\subsection{Vatan-ı Seferî Olarak "Sevgilinin Kûyu"}

Zaman zaman Âşık için, sevgilinin kûyu bile, dağ ve çölün yanında vatan-1 seferîdir. Âşsk, sevgilinin kûyunda hayrete daha fazla dayanamayarak aslî vatanına döner:

Nizâmî:

Çektiği gamın şiddetinden deliliği tutmuş / Birden cinlenerek dağının yolunu tutmuş

Necid Dağı'na çıkıp feryat, figan etmiş / Dövünmüş, kendi yüzüne tokat aşketmiş (2050-51)

\footnotetext{
${ }^{90}$ Ayrıca bk.: Sevdâyî, 382-84; Celalzade Salih, 890-1, Andelî̉b, s.62

${ }^{91}$ Behiştî için bk.: 1303; Andelîb için bk.: s.52;
} 


\section{Şâhidî:}

Bunı didi vü pür tâb oldı çün tîr / Yeñilmedi delürdi kopdı zencîr $\cdots$

Sipâh-1 gamla idüb dâr u gîri / İrişdi Necd'e varurdı nefî̀i (2511-13)

\section{Hamdullah Hamdî:}

Didi bunı atıldı nitekim tîr / Delülük tâzelendi kırdı zencîr

K1lup mihrâb-1 yâra karşu secde / Semâ' u vecd ile 'azm itdi Necd'e (1941-2)

\section{Ahmed-i Rudvan:}

Bunı didi revân yil bigi esdi / Kaçub dīvâneveş zencīri kesdi

Gice gündüz dimedi sürdi gitdi / Gine yârı kuhun dağına yitdi (88a) ${ }^{92}$

\subsection{Vatan-ı Seferî Olarak "Maşuğun Kabri”"}

Âş1k, tıpkı sevgilinin kûyunda olduğu gibi, sevgilinin bir başka mekânı olan kabrinde de daha fazla kalamaz ve aslî vatanları olan dağ ve çöle döner:

\section{Nizâmî:}

Bunları söyleyip ellerini birleştirmiş / Dönüp etrafını saran kalabalığı yarmış

Yola çıkıp kendi yurduna doğru gitmiş / Bir grup yabani hayvan da yanında gitmiş (3525-6)

\section{Behiştî:}

Didi bunı vü kodı dest-ber-dest / Dönüp raks ile Necd'e girdi ser-mest (3829)

\subsection{Vatan-ı Seferî Olarak "Anne-Babanın Kabri”"}

Âşık, anne-babası vefat ettikten sonra, onların kabirlerini pişmanlık ile ziyarete gider. Ancak, her ne kadar nedamet getirse de aşkın vatanları olan dağ ve çöle dönmekten kendini alamaz:

\section{Nizâmî:} yerden

Yürüyen toprak gibi Mecnûn kalkmış yerinden / Üzüntü içinde, Necid Dağı'na gitmiş o

Her gün bir belayla karşılaştığı çölde / Yolu sevgilinin diyarına düşmüş çölde (2510-2517)

\section{Şâhidî:}

Bir âh k1ld1 vü tutdı râh-1 kûh1 / Getürdi rahtı terk itdi gürûh1

${ }^{92}$ Celalzade Salih için bk.: 1795-97; Nâkâm için bk.: s.68 
Fenâya kim tutupdı berk veş râh / Cihândan kılmışıdı dest-i kûtâh (3645-48)

\section{Hamdullah Hamdî:}

Ki ol sahrâ-bisât u kûh-bâlîn / Yetîm ü 'âş1k u Mecnûn-1 miskîn

Çü fârig oldı pîrün mateminden / Yine kaçdı tekellüf 'âleminden (2608-9) ${ }^{93}$

\section{Ahmed-i Rudvan:}

Atası kabrinüñ çün terkin itdi / Gine deştile kûha düşdi gitdi (94b)

\section{Fuzûlî:}

Çün müşg tökildi gerd-i kâfur / Zulmâta bırahdı pertevin nûr İhyâ kıluben merâsim-i vecd / Dutdı reh-i gûr-hâne-i Necd (2205-6)

\section{Larendeli Hamdî:}

Anne ve babasının vefatından sonra Mecnûn, kendisini velîahd olarak görmek isteyen kabilesinin bu talebini reddederek tekrar dağa döner:

Çok itdiler eve iletmeğe cehd / Ki varub ola mülkine veli-'ahd

Yine eyledi 'azm-i kûh Mecnûn / Yine başladı gözden dökmeğe hûn (3831-34)

Andelîb'de, Mecnûn babasının kabrinde üç gün kalıp Kur'an-1 Kerim okuduktan sonra tekrar çöllere döner:

“... yine çöl beyâbânğa yüz urup kûh be kûh, deşt be deşt yörürdi”, (s.103). ${ }^{94}$

\section{Sonuç}

Türk edebiyatında 19. yüzyılda ön plana çıkmaya başlamış olan "vatan" temi, divan edebiyatındaki vatan algısı ve mahiyeti konusunun incelenmesi ihtiyacını doğurmuştur. Araştırmalarda, divan şiirindeki vatan algısının, dünyevî ve siyasî-sosyal boyuttan bağımsız olarak daha çok müteâl bir anlamı karşıladığı sonucuna ulaşılmıştır.

Divan şiirinde vatan, dar anlamda, kişinin ait olduğu yeri ifade etmekte, manevî anlamda ise ruhun ait olduğu yeri karşılamaktadır. Ruhun ait olduğu yer; bezm-i elest ve cennet çerçevesinde değerlendirilirken âşığın ruhunun ait olduğu sevgilinin kûyu da vatan kapsamında düşünülmektedir. Ait olunan yerler vatan-1 aslî, geçici olarak kalınan yerler ise, vatan-1 seferîdir.

Vatanın, aslî ve seferî çeşitlerinin bulunması, vatan kavramının "mutlak mevcudiyet"inden haber vermektedir. Mekândan kaynaklanan imgesel varlık, varoluşun, mekân ve mekân üzerine kurulu zaman ile birlikteliğini ortaya koymaktadır. Zamanın tahakkümü, hiç şüphesiz mekânın varlığı ile mümkündür. Mekânın varlığı, imgesel olarak dünya üstü bir varlık ve mahiyete sahiptir. Mekâna bağlı olarak vatan da aynı şekilde dünya üstü bir özden kaynaklanmaktadır.

\footnotetext{
${ }^{93}$ Ayrica bk.: 3146.

${ }^{94}$ Ayrıca bk.: Mektebî için Levend, 1959: 62, 69, 70; Celîlî: 1801-8, Nâkâm : s.112-13
} 
Dünyadaki her unsurun, bir ilk imgeden kaynaklandığı anlayışı çerçevesinde, vatan, bir "idea", bir "arketip" olarak ortaya çıkmaktadır. İdea ve arketip, Platon ve Jung'un tercih ettiği kavramlar olarak birebir aynı manâyı karşılamamakla birlikte, fenomenlerin numen özlerine dikkat çekmeleri bakımından eşit kabul edilebilir. İbnü'l-Arabî, aynı mahiyeti "ayân-ı sabite" kavramı ile karşılar. İbnü'l-Arabî’nin "ayân-1 sabite" olarak belirttiği sabit özler, idea ve arketiplerin esasını teşkil etmektedirler. İdea, arketip ve ayân-1 sabite, sonuçta, belli noktalarda ayrışıp birleşirler. Esasında ise, dünyadaki varlık unsurlarının dünya üstü değişmez mahiyetlerine işaret etmeleri bakımından ortak bir manayı içermektedirler.

Vatanın imgesel varlı̆̆ı, İbnü'l-Arabî'nin izah ettiği konular arasındadır. İbnü'l-Arabî'ye göre, vatanların sayısı çok olmakla birlikte, insanın bulunduğu vatanlar altı tanedir. Bunlar: bezm-i elest, dünya, berzah, haşr, cennet-cehennem ve Kum Tepesi (el-Kesîb)'dir. Bezm-i elest, ilk vatanı, dünya ikinci vatanı oluşturmaktadır. Ölümden sonraki vatan, berzah; hesap günü toplanılacak olan vatan ise haşrdır. Kişinin, amellerine göre tayin edilen vatanlar ise, cennet ve cehennemdir. Son vatan, Rabb'in görüleceği Kum Tepesi (el-Kesîb)'dir. El-Kesîb, Firdevs cennetinin dışında olup kişinin amel seviyesine göre bulunacağı vatandır.

Dinî-tasavvufî mahiyeti ile öne çıkan divan edebiyatı, her varlık ve kavrama, ideal yönü bakımından yaklaşır. Vatan kavramının, siyasî-sosyal manâdan bağımsız olarak özellikle dinîtasavvufî anlamı ile ele alınması hususu da bu yaklaşımlardan birini oluşturmaktadır. Divan şiirinde, sevgilinin müteâl varlığı karşılaması yanında, onunla ilgili varlık unsurlarının da idealize edilmesi, vatan kavramına bakışı da aynı derecede etkilemiştir. Şairler için, divanlarda, vatan, müteâl varlığa vasıl olunacak mekânlar olması bakımından, özellikle bezm-i elest ve cennetten ibarettir. Ruhun, ait olduğu yeri vatan olarak görme anlayışı, vatanın, ifade edilen arketipsel mahiyetinden kaynaklanmaktadır. Bu mahiyet, âşıkların, sevgilinin bulunduğu mahalli aslî vatan olarak görme anlayışını da beraberinde getirmektedir. Mecazî sevgilinin, ilahî sevgilinin bazı vasıflarının bir sûreti, yansıması olması, sevgilinin kûyunun da ilahî sevgiliye vasıl olunan vatanın bir sûreti ve yansıması olduğu anlayışını doğurmaktadır. Böylece, bezm-i elest ve cennetin yanında, mecazî sevgilinin kûyu da Ka'be gibi, âşı̆̆ın aslî vatanlarından birini oluşturmaktadır.

Asıl sevgiliye ulaşma noktasında aklı âciz bırakan aşk, âşığın kalbini mesken tuttuğunda, âşık için herhangi bir yerde karar etme imkânı yoktur. Divan şiirinde âşıklar, bu nedenle, âşık oldukları andan itibaren içlerinde bulundukları mekânlara sığamaz olurlar. Âşı̆̆ın mekânsızlığı, eserlerde, "lâ-mekân" ve "bî-karâr" olarak tavsif edilir. Herhangi bir yeri mesken tutamayan âşı̆̆ın bu nedenle nerede olduğu bilinemez. Ancak, vatan ve tavattun bir arketiptir. Dünya vatanı içinde bulunan âşığın, baba evi olan eski vatanını terk etmesi, yeni mekânlar edinme sonucunu kaçınılmaz olarak beraberinde getirecektir. Âşık, âşı olmadan önce, vatan tuttuğu baba ocağını terk edip kendisine genellikle dağları ve çölleri, zaman zaman mağarayı, sevgilinin kûyu ve kabrini mesken tutar. Âşığın aslî vatanları böylece, söz konusu mekânları kapsar. Âşık, bu vatanlarda bir dönüşüm sürecine tâbi ve bağlıdır. Mekânların mahiyeti, âşığın seçtiği vatanların nedenini ortaya koyması bakımından önem arz eder.

Divan şiirinde âşıkların şâhı olan kahraman, Mecnûn'dur. Mecnûn'un mecazdan hakikate olan seferi, şairlerin, Ferhâd ve Cemşîd'i de aynı minvalde âşıklar olarak idealize etmelerine sebep olmuştur. Leylâ vü Mecnûn mesnevîlerinde görülen özellikle aslî vatan unsurları, bu bakımdan, Hüsrev ü Şîîn ve Ferhâd u Şîrîn ile Cemşîd ü Hurşîd mesnevîlerinde de görülür. Mecnûn, Ferhâd ve Cemşîd; Leylâ, Şî̀în ve Hurşîd'e olan aşklarından ilahî aşka geçiş süreçlerinde, kendilerine dağları, çölleri ve sevgilinin kûyunu vatan edinmişlerdir. Vatan-1 aslîlerin varlığı, zaman ve mekâna bağlı bir varlık olan insanın dönüşüm sürecinde, etkin varlık unsurları olarak ön plana çıkmaktadır. Mecnûn, Ferhâd ve Cemşîd, dikey boyutu temsil eden dağ ve yatay boyutu temsil eden çöl ile sevgilinin kûyunda madden bulunarak manevî boyuttaki seyr ü seferi gerçekleştirmişlerdir. Bu bakımdan, aslî unsurlar olarak görülen vatanların, âşıkların dönüşümlerinde etkin bir rol oynadığı görülmüştür. 


\section{Kaynakça}

Abdel-Maksoud, B. (2004). Leylâ ile Mecnûn Mesnevîsinin Arap, Fars ve Türk Edebiyatında Ele Alınış Biçimi ve Lârendeli Hamdî'nin Eseri [Yayımlanmamış doktora tezi]. İstanbul Üniversitesi Sosyal Bilimler Enstitüsü.

Ahmed-i Ridvan. Leylâ vü Mecnûn. Atatürk Üniversitesi Merkez Kütüphanesi, Seyfettin Özege Bölümü, ASL 414.

Akalın, M. (1975). Ahmedî Cemşî̀d ü Hurşî̀d (İnceleme-Metin). Sevinç Matbaası.

Akarsu, B. (2016). Felsefe Terimleri Sözlüğü. İnkılap Kitabevi Yayın Sanayi ve Ticaret AŞ.

Ali Şir Nevâyi (2011). Leyli vü Mecnûn. Haz. Ülkü Çelik Şavk. Türk Dil Kurumu Yayınları.

Alpay-Tekin, G. (2012). Ali-Şîr Nevâyı̂ Ferhâd ü Şî̀în. Türk Dil Kurumu Yayınları.

Alper, K. (2018). Nâkâm ve Ferhâd ü Şîrîn Mesnevîsi. Akademik Sosyal Araştırmalar Dergisi 6 (82), $462-521$.

Atar, F. (2009). Sefer. TDV İslam Ansiklopedisi 36, 294-298.

Atâyî. Leylâ ile Mecnûn. Atatürk Üniversitesi Merkez Kütüphanesi, Seyfettin Özege Bölümü, ASL 644.

Ayan, E. (2010). Sâlim Efendi'nin Husrev ü Şîrîn Mesnevîsi ve Türk Edebiyatından Husrev ü Şîîn Mesnevîleri [Yayımlanmamış doktora tezi]. Hacettepe Üniversitesi Sosyal Bilimler Enstitüsü.

Aygün, Z. A. (1999). Behiştî’nin Leylâ vü Mecnûn Mesnevîsi (İnceleme-Metin). [Yayımlanmamış doktora tezi]. Çukurova Üniversitesi Sosyal Bilimler Enstitüsü.

Azeri İbrahim Çelebi (2019). Hüsrev ü Şî̀în. (Haz. Ülkü Çetinkaya Karakoyun). Türk Dil Kurumu Yayınları.

Bachelard, G. (2017). Mekânın Poetikası. Çev. Alp Tümertekin. İthaki Yayınları.

Banarlı, N. S. (1972, Ekim 1). Edebiyatımızda Vatan Sevgisi ve Fikret'in Vatancılı̆̆ı. Kubbealtı Akademi Mecmuast. 1(4), 53-64.

Bayak, C. (2019). Sevdâŷ̂ Kıssa-i Birle Leyli. Kültür ve Turizm Bakanlığı Yayınları.

Bolay, S. H. (1988). Âdem. TDV İslam Ansiklopedisi 1, 358-363.

Câmî (1313), Leylî vu Mecnûn, (Haz.: Vâhid-i Destgirdî, 2016).

Cevizci, A. (2020), Büyük Felsefe Sözlüğü, Say Yayınları.

Çağrıc1, M. (2012). Vatan. TDV İslam Ansiklopedisi 42, 563-564.

Devellioğlu, F. (2003). Osmanlıca-Türkçe Ansiklopedik Lûgat. Aydın Kitabevi.

Dinî Terimler Sözlüğü (2009). MEB Yayınları.

Doğan, M. N. (2010). Fuzûlî Leylâ ve Mecnûn. Yelkenli Yayınevi.

Ebî Bekr el-Vâlibî, Divanu Mecnun Leylî, (Haz.: Ali Hasan, 1987), Mektebetü'l-Âdâb ve Matbatühâ Bi'l-Câmîz, Misır.

Ebu'l-Alâ Afîfî (2018). Tasavvuf İslâm'da Manevî Hayat. Çev. Ekrem Demirli-Abdullah Kartal. İz Yayıncilik. 
Emini, N. G. (1996). Selman-ı Saveci ve Cemşî̀d ü Hurşîd Mesnevîsi. [Yayımlanmamış yüksek lisans tezi]. Ankara Üniversitesi Sosyal Bilimler Enstitüsü.

Emir Hüsrev-i Dihlevî (1964). Mecnûn u Leyli. (Haz. Tahir Ahmed Oğlu Muharremof).

Erbay, N. (2012). Edirneli Şâhidî’nin Leylâ vü Mecnûn (Gülşen-i Uşşâk) Mesnevîsi (İncelemeTenkitli Metin) [Yayımlanmamış doktora tezi]. Atatürk Üniversitesi Sosyal Bilimler Enstitüsü.

Eren, A. (2018). Klâsik Türk Şiirinde Tasavvufî̀ Açıdan Tûr-1 Sînâ. Rumelide Dil ve Edebiyat Araştımaları Dergisi Özel Sayı 4 (Ăgustos), 197-210.

Esir, H. A. (2017). Lami '̂̀ Çelebi Ferhâd ile Şîrîn. Kültür ve Turizm Bakanlığı Yayınları.

Gökberk, M. (2018). Aydınlanma Felsefesi, Devrimler ve Atatürk. Kırmızı Kedi Yayınevi.

Guénon, R. (2019). Yatay ve Dikey Boyutların Sembolizmi. İnsan Yayınları.

Güler, Z. (1982). Hamdullâh Hamdî Leylâ vü Mecnûn [Yayımlanmamış doktora tezi]. Atatürk Üniversitesi Sosyal Bilimler Enstitüsü.

Gülmez, M. (2003). Fahrî̀nin Husrevü Şîrîn'i (Metin-Gramer-Sözlük) [Yayımlanmamış doktora tezi]. Selçuk Üniversitesi Sosyal Bilimler Enstitüsü.

Hacieminoğlu, M. N. (2000). Kutb’un Hüsrev ü Şîrîn’i ve Dil Hususiyetleri. Atatürk Kültür, Dil ve Tarih Yüksek Kurumu Türk Dil Kurumu Yayınları.

Hâtifî. Leylî vü Mecnûn. İstanbul Üniversitesi Kütüphanesi, No: 68 v.1b.

İbn Arabî (2019). Fususu'l-Hikem. Çeviri ve Şerh: Ekrem Demirli. Alfa Araştırma Yayınları.

İbnü'l-Arabî (2009). Manevî Seferler (El-İsfâr an Netâici'l-Esfâr). Çev. Muhammed Bedirhan. Nefes Yayınevi.

İnce, A. (2000). Cem Sultan Cemşîd ü Hurşîd. Türk Kültür, Dil ve Tarih Yüksek Kurumu Türk Dil Kurumu Yayınları.

İsmail Ankaravî Dede (2020), Merâtib-i Sülûk (Sülûkun Mertebeleri)ve Yüz Mertebe.

http://dosyalar.semazen.net/e_kitap/Yuz_Mertebe.pdf

İsmayıl Bəy Nâkâm (2007). Macnun və Leyli. (Haz. Yolçu Piriyev).

Jung, C. G. (2017). Dört Arketip. Çev. Zehra Aksu Yılmazer. Metis Yayınları.

Kılıç, M. E. (1995). Muhyiddîn İbnu'l-Arabî'de Varlık ve Mertebeleri [Yayımlanmamış doktora tezi]. Marmara Üniversitesi Sosyal Bilimler Esntitüsü.

Koçak, A. (2006). Leylâ vü Mecnûn (Tebrizli Hakîrî) [Yayımlanmamış yüksek lisans tezi]. Marmara Üniversitesi Türkiyat Araştırmaları Enstitüsü.

Kuloğlu, N. (1989). Abdî Cemşîd ü Hurşîd [Yayımlanmamış yüksek lisans tezi]. Fırat Üniversitesi, Sosyal Bilimler Esntitüsü.

Kutluer, İ. (2003). Mekân. TDV İslam Ansiklopedisi 28, 550-552.

Kütük, R. (1995). Celal-zade Salih Çelebi Leylâ vü Mecnûn (Tenkidli Metin-İnceleme) [Yayımlanmamış yüksek lisans tezi]. Atatürk Üniversitesi Sosyal Bilimler Enstitüsü.

Kütük, R. (2002). Lârendeli Hamdî’nin Leylâ vü Mecnûn Mesnevîsi (İnceleme/Metin ve Diğer Leylâ ve Mecnûn Mesnevîleriyle Mukayesesi) [Yayımlanmamış doktora tezi]. Atatürk Üniversitesi Sosyal Bilimler Enstitüsü. 
Levend, A. S. (1959). Arap, Fars ve Türk Edebiyatlarında Leylâ ve Mecnûn. Türk Tarih Kurumu Basımevi.

Levend, A. S. (1984). Divan Edebiyatı. Enderun Kitabevi.

Lewis, B. (2018). Modern Türkiye'nin Doğuşu. Arkadaş Yayınevi.

Muhammed Hacı Yusuf (2019). İbnü'l-Arabî Zaman ve Kozmoloji. Nefes Yayıncılık.

Muhyiddin İbn Arabî (2018). Nurlar Risalesi. Çev. Mahmut Kanık. İnsan Yayınları.

Mutçalı, S. (1995). Arapça-Türkçe Sözlük. Dağarcık Yayınevi.

Nas, Ş. K. (2011). Celîlî’nin Leylâ vü Mecnûn Mesnevîsi. Fakülte Kitabevi Yayınları.

Nas, Ş. K. (2017). Celîlî’nin Hüsrev ü Şî̀în Mesnevîsi (İnceleme-Metin). Palet Yayınları.

Nicholson, R. A. (2018). Tasavvufun Menşei Problemi. Çev. Dr. Abdullah Kartal. İz Yayıncılık.

Nizâmî (2012). Hüsrev ile Şîrîn. Çev. Sabri Sevsevil. Kabalcı Yayınları.

Nizâmî-yi Gencevî (2013). Leylâ ile Mecnûn. Çev. A. Naci Tokmak. Say Yayınları.

Nur Mehemmed Endelib (1378). Leyli-Mecnûn. Haz. Çerkez Evnak.

Özcan, N. (2007). Şâĥi’nin Ferhâdnâme'si (İnceleme-Metin) [Yayımlanmamış doktora tezi]. Gazi Üniversitesi Sosyal Bilimler Enstitüsü.

Pala, İ. (2012). Ansiklopedik Divan Şiiri Sözlüğü. Kapı Yayınları.

Platon (2007). Devlet. Çev. Hüseyin Demirhan. Palme Yayıncılık.

Sağlam, H. (2020). Motif Yapısı İtibariyle Leylâ ve Mecnûn Mesnevîleri Üzerinde Bir İnceleme. [Yayımlanmamış doktora tezi]. Ankara Yıldırım Beyazıt Üniversitesi Sosyal Bilimler Enstitüsü.

Sarı, M. (2016). Divan Şiirinde Vatan. Hikmet-Akademik Edebiyat Dergisi. Prof. Dr. Mine Mengi Özel Saylsı, 2 (5), 209-244.

Solak, A. (2003). Leylâ vü Mecnûn Hikâyesi (Metin-İnceleme-Dizin-Tıpkıbasım) [Yayımlanmamış yüksek lisans tezi]. Marmara Üniversitesi Türkiyat Araştırmaları Enstitüsü.

Sütçü, T. (2004). Tanzimat Sonrası Türk Edebiyatında Vatan Temi [Yayımlanmamış doktora tezi]. İstanbul Üniversitesi Sosyal Bilimler Enstitüsü.

Şahbaz, M. (2018). İslam Öncesi Türklerde Dağ Kültü ve İnancı. Social Sciences Studies Journal, 4 (19), 2250-2261.

Şemseddin Sami (1987). Kâmûs-ı Türkî. Çağrı Yayınları.

Tavukçu, OK. (2000). Ahmed Rıdvan Hüsrev ü Şîrîn (İnceleme-Metin) [Yayımlanmamış doktora tezi]. Atatürk Üniversitesi Sosyal Bilimler Enstitüsü.

TDK Sözlüğ̈̈ (2005). TDK Yayınları.

Timurtaş, F. K. (1963). Şeyhî'nin Hüsrev ü Şîrîn'i. İstanbul Üniversitesi Edebiyat Fakültesi Basimevi.

Uludağ, S. (1991). Ayân-ı Sabite. TDV İslam Ansiklopedisi 4, 198-199.

Uludağ, S. (2008). Ricâlü'l-Gayb. TDV İslam Ansiklopedisi 35, 81-83.

Ülken, H. Z. (2008). Felsefeye Giriş I. Türkiye İş Bankası Kültür Yayınları. 
Vatan Arketipi Bağlamında Âşıkların (Mecnûn, Ferhâd, Cemşîd) Vatan-1 Aslî ve Vatan-1...

Üst, S. (2014). Hüsrev, Şîrîn ve Ferhâd Kahramaları Üzerine. A.Ü. Türkiyat Araştırmaları Enstitüsü, $51,47-62$.

Yavuz, Y. Ş. (2001). İstivâ. TDV İslam Ansiklopedisi 23, 402-404. 